\title{
Coordinated Cluster/Double Star and ground-based observations of dayside reconnection signatures on 11 February 2004
}

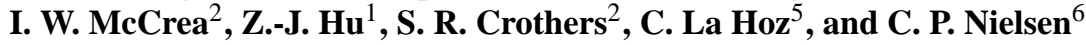 \\ ${ }^{1}$ SOA Key Laboratory for Polar Science, Polar Research Institute of China, Shanghai, China \\ ${ }^{2}$ Space Science Department, Rutherford-Appleton Laboratory, Chilton, Didcot, UK \\ ${ }^{3}$ Department of physics and Astronomy, University of Leicester, Leicester, UK \\ ${ }^{4}$ Mullard Space Science Laboratory, University College London, Dorking, Surrey, UK \\ ${ }^{5}$ Department of Physics, Faculty of Science, University of Troms $\varnothing, 9037$ Troms $\varnothing$, Norway \\ ${ }^{6}$ Norwegian Polar Institute, Sverdrupstasjonen, 9173 Ny-Alesund, Norway
}

Q.-H. Zhang ${ }^{1}$, M. W. Dunlop ${ }^{2}$, R.-Y. Liu ${ }^{1}$, H.-G. Yang ${ }^{1}$, H.-Q. Hu ${ }^{1}$, B.-C. Zhang ${ }^{1}$, M. Lester ${ }^{3}$, Y. V. Bogdanova ${ }^{4}$,

Received: 27 November 2010 - Revised: 29 August 2011 - Accepted: 13 October 2011 - Published: 24 October 2011

\begin{abstract}
A number of flux transfer events (FTEs) were observed between 09:00 and 12:00 UT on 11 February 2004, during southward and dawnward IMF, while the Cluster spacecraft array moved outbound through the northern, highaltitude cusp and dayside high-latitude boundary layer, and the Double Star TC-1 spacecraft was crossing the dayside low-latitude magnetopause into the magnetosheath south of the ecliptic plane. The Cluster array grazed the equatorial cusp boundary, observing reconnection-like mixing of magnetosheath and magnetospheric plasma populations. In an adjacent interval, TC-1 sampled a series of sometimes none standard FTEs, but also with mixed magnetosheath and magnetospheric plasma populations, near the magnetopause crossing and later showed additional (possibly turbulent) activity not characteristic of FTEs when it was situated deeper in the magnetosheath. The motion of these FTEs are analyzed in some detail to compare to simultaneous, poleward-moving plasma concentration enhancements recorded by EISCAT Svalbard Radar (ESR) and "polewardmoving radar auroral forms" (PMRAFs) on the CUTLASS Finland and Kerguelen Super Dual Auroral Radar Network (SuperDARN) radar measurements. Conjugate SuperDARN observations show a predominantly two-cell convection pattern in the Northern and Southern Hemispheres. The results are consistent with the expected motion of reconnected magnetic flux tubes, arising from a predominantly sub-solar reconnection site. Here, we are able to track north and south in closely adjacent intervals as well as to map to the corresponding ionospheric footprints of the implied flux tubes and demonstrate these are temporally correlated with clear iono-
\end{abstract}

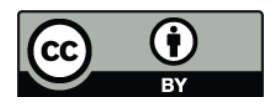

Correspondence to: Q.-H. Zhang (zhangqinghe@pric.gov.cn) spheric velocity enhancements, having northward (southward) and eastward (westward) convected flow components in the Northern (Southern) Hemisphere. The durations of these enhancements might imply that the evolution time of the FTEs is about 18-22 min from their origin on magnetopause (at reconnection site) to their addition to the magnetotail lobe. However, the ionospheric response time in the Northern Hemisphere is about 2-4 min longer than the response time in the Southern Hemisphere.

Keywords. Magnetospheric physics (Magnetopause, cusp, and boundary layers; Magnetosphere-ionosphere interactions) - Space plasma physics (Magnetic reconnection)

\section{Introduction}

Magnetic reconnection is a fundamental plasma process, resulting in energy and momentum transfer from the solar wind to the magnetosphere. This process was first discussed in terms of a steady process by Dungey (1961) and was later discovered to show an independently intermittent and spatially limited nature by Haerendel et al. (1978) and then Russell and Elphic (1978) on the dayside magnetopause. The associated sampled, magnetic signatures arising from the passage of bundles of reconnected flux nearby a spacecraft were named flux transfer events (FTEs) by Russell and Elphic (1978). This term was originally designed to characterize the signatures according to their bipolar signature in the magnetic field component normal to the magnetopause. Subsequent studies detailed the intricate mixing of magnetosheath and magnetospheric plasma populations associated with these signatures (e.g. Daly et al., 1981; Thomsen et al., 1987; Farrugia et al., 1988), their accelerated ion flows (e.g.

Published by Copernicus Publications on behalf of the European Geosciences Union. 
Paschmann et al., 1982) and their larger occurrence rate during periods of southward interplanetary magnetic field (IMF) (e.g. Berchem and Russell, 1984; Lockwood and Smith, 1992). Statistical studies (e.g. Rijnbeek et al., 1984; Lockwood, 1991; Lockwood and Wild, 1993) have also shown that the mean interval between FTE signatures is of the order of 8 min. However, Lockwood and Wild (1993) showed that the distribution of these intervals has a mode value at $3 \mathrm{~min}$, with upper and lower decile values of 1.5 and $18.5 \mathrm{~min}$, respectively.

Because of the limitation of single-point spacecraft measurements at the magnetopause, it is difficult to determine the spatial distribution and motion of FTEs. Furthermore, the in-situ space observations are associated with the response of the ionosphere and ground geomagnetic field. The early work of Elphic et al. (1990) demonstrated that ionospheric flow bursts measured by EISCAT were associated with FTEs observed by ISEE and the first magnetically conjugate measurements of an FTE by Equator-S and of ionospheric flow bursts by SuperDARN were presented by Neudegg et al. (1999). The UV aurora measured by the Polar spacecraft's VIS (Visible Imaging System) Earth camera in the vicinity of the reconnection footprint for this event was later discussed (Neudegg et al., 2001). Recently, Cluster (Escoubet et al., 2001) observations of FTEs (e.g. Owen et al., 2001; Fear et al., 2005; Zheng et al., 2005; Hasegawa et al., 2006; Wang et al., 2005) have been combined with a variety of ground-based instruments (e.g. Lockwood et al., 2001; Wild et al., 2001, 2003; Marchaudon et al., 2004; Zhang et al., 2008, 2010).

Following the successful launch of Double Star, it is now possible to study FTEs from five or six points in space simultaneously. For example, the first magnetically conjugate observations of FTEs by Cluster and Double Star TC- 1 at the Northern and Southern Hemisphere, respectively, were presented by Dunlop et al. (2005) and coordinated Cluster/Double Star and ground-based measurements of FTEs were reported by Wild et al. $(2005,2007)$. Nevertheless, the evolution of a flux tube (FTE), from its generation at the magnetopause to its disappearance in the global magnetospheric convection (Amm et al., 2005) is not well tied to the location of reconnection onset or the development of the reconnection rates.

In this paper, we analyze several medium to large scale FTEs which were observed by the Cluster array, at the highlatitude magnetopause, or by the TC-1 spacecraft, south of the subsolar magnetopause, simultaneously measured by the ESR and conjugately observed by the CUTLASS Finland and Kerguelen SuperDARN radars (also observing the ionospheric plasma flow, Greenwald et al., 1995; Chisham et al., 2007) measuring the global ionospheric convection. These FTEs are interpreted as reconnection generated signatures. All FTEs observed by Cluster and TC-1 have some reconnection features in the plasma data: some of these FTEs, especially observed by TC-1, contain an accelerated mag- netosheath population, and the others contain a mixture of magnetospheric and magnetosheath plasma populations. Using the Cluster 4-spacecraft observations, we calculate the velocity and the size of the implied flux tubes connected to the northern cusp. The ESR measurements, record poleward flows and the CUTLASS Finland and Kerguelen SuperDARN radar observations show "poleward-moving radar auroral forms" (PMRAFs), also indicative of bursty reconnection at the dayside magnetopause. The SuperDARN observations show that the individual flux tube movements, which contain predominantly northward (southward) or eastward (westward) components, map to positions in the ionospheric convection cells in the Northern (Southern) Hemisphere which have the corresponding flow directions. Moreover, we verify that the movements of the reconnected flux tubes are well consistent with the Cooling model (Cooling et al., 2001), which predicts the expected motion of reconnected flux tubes, given the prevailing IMF and sheared solar wind flow. We also comment on other features of the data, focusing on additional magnetic activity at TC-1.

\section{Observations}

\subsection{Upstream solar wind and IMF conditions}

Figure 1 presents an overview of the solar wind and IMF conditions measured by the ACE satellite. Parameters shown are IMF components (a) $B_{\mathrm{X}}$, (b) $B_{\mathrm{Y}}$, (c) $B_{\mathrm{Z}}$, (d) IMF clock angle, (e) solar wind plasma number density, (f) solar wind speed, and (g) solar wind dynamic pressure. The data have been lagged by $69 \mathrm{~min}$ before 10:00 UT (lagged time) and 66 min after 10:00 UT (this time delay is calculated using the method of Liou et al., 1998) in order to take into account the propagation of solar wind/IMF structure from the spacecraft to the subsolar magnetopause. The ACE spacecraft is located at about $(221.2,-32.6,9.5) R_{\mathrm{E}}$ in the Geocentric Solar Magnetic (GSM) coordinate system at about 10:34 UT (lagged time). During whole interval, the IMF $B_{\mathrm{Z}}$ component was near zero before about 09:30 UT (lagged time) and always negative, varying between -8.2 to $-0.4 \mathrm{nT}$ (see Fig. 1c), after 09:30 UT, while the $B_{Y}$ component was negative with a short, positive incursion (see Fig. 1b). The IMF clock angle (if $B_{\mathrm{Z}}>0$, clock angle $=\operatorname{atan}\left(\left|B_{\mathrm{Y}}\right| / B_{\mathrm{Z}}\right.$ ), and if $B_{\mathrm{Z}}<0$, the clock angle $\left.=\pi-\operatorname{atan}\left(\left|B_{\mathrm{Y}}\right| / B_{\mathrm{Z}}\right)\right)$ therefore varied between $90^{\circ}$ and $180^{\circ}$ during this period (see Fig. 1d). The solar wind density increased from 7 to $19 \mathrm{~cm}^{-3}$ over the interval of interest (see Fig. 1e), whilst the solar wind velocity varied between 370 and $387 \mathrm{~km} \mathrm{~s}^{-1}$ (see Fig. 1f), resulting in a prevailing solar wind dynamic pressure of $\sim 1.8-4.5 \mathrm{nPa}$ (see Fig. 1g).

\subsection{Spacecraft and ground coverage}

The Cluster spacecraft (Escoubet et al., 2001) were launched in pairs in July and August 2000 into elliptical, polar orbits 


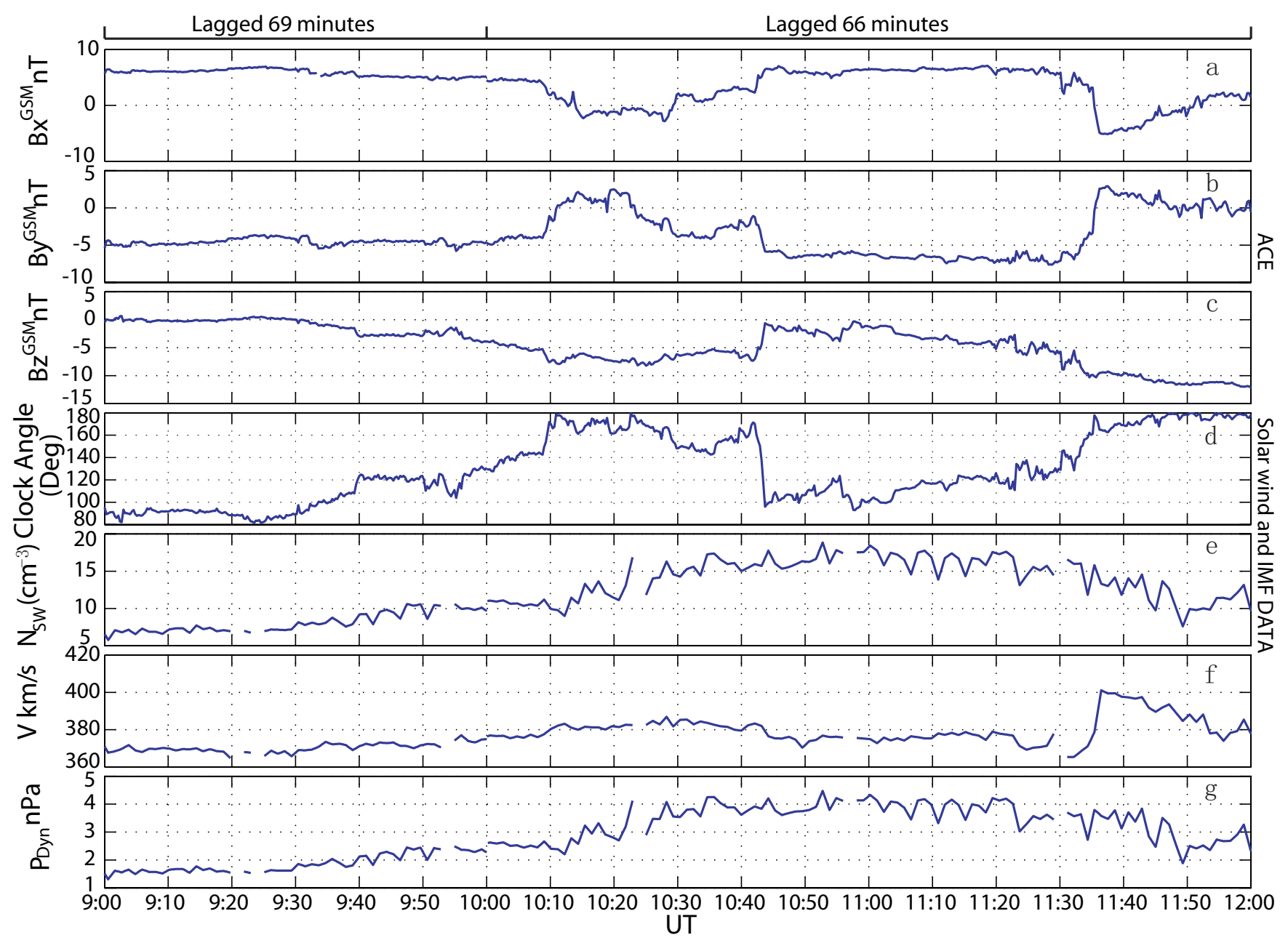

Fig. 1. An overview of the solar wind and IMF conditions measured by the ACE satellite. Parameters shown are IMF components (a) $B_{X}$, (b) $B_{\mathrm{Y}}$, (c) $B_{\mathrm{Z}}$, (d) IMF clock angle, (e) solar wind plasma number density, (f) solar wind speed, and (g) solar wind dynamic pressure.

with a perigee at $\sim 4 R_{\mathrm{E}}$, an apogee at $\sim 19.6 R_{\mathrm{E}}$ and identical orbital periods of $57 \mathrm{~h}$. The average distance of each two spacecraft is about $300 \mathrm{~km}$ in February 2004. Data with $4 \mathrm{~s}$ resolution from the fluxgate magnetometer (FGM) (Balogh et al., 2001) on all four Cluster satellites and from the Plasma Electron and Current Experiment (PEACE) (Johnstone et al., 1997) and from Cluster Ion Spectrometry (CIS) (Rème et al., 2001) onboard Cluster S/C 1 are used in this study. One of the two Double Star spacecraft, TC-1 (Liu et al., 2005) was launched in December 2003 into an equatorial orbit at $28.2^{\circ}$ inclination, with a perigee altitude of $577 \mathrm{~km}$, an apogee of $13.4 R_{\mathrm{E}}$, and an orbital period of $27.4 \mathrm{~h}$. Data with $4 \mathrm{~s}$ resolution from FGM (Carr et al., 2005) and from PEACE (Fazakerley et al., 2005) instruments onboard TC-1 are used in this paper.

Figure 2 shows the tracks of all Cluster and the TC1 spacecraft between 09:00 and 13:00 UT on 11 February 2004, in the X-Z (a) and X-Y (b) planes, in the GSM coordinate system, with the configuration of the Cluster space- craft array drawn as a tetrahedron (size scaled up by a factor of 20). Model geomagnetic field lines are shown for the projection into the $\mathrm{X}-\mathrm{Z}$ plane and cuts through the bow shock (BS) and magnetopause (MP) are shown for the XY plane. The ionospheric footprints of Cluster spacecraft 1 (in blue line) and TC-1 (in red line) spacecraft on the maps of Northern (c) and Southern (d) Hemispheres in geographic coordinate system are shown in the lower panels. The X-Z plane field lines and ionospheric footprints of the spacecraft are drawn from the Tsyganenko '96 model (Tsyganenko and Stern, 1996) with input parameters: $P_{\text {Dyn }}=3.93 \mathrm{nPa}$ (the solar wind dynamic pressure), IMF $B_{\mathrm{Y}}=-4.00 \mathrm{nT}$, IMF $B_{\mathrm{Z}}=-5.92 \mathrm{nT}$ and Dst $=-1 \mathrm{nT}$. These parameters represent the average IMF and solar wind conditions during the interval of interest. During this interval all spacecraft are outbound from the magnetosphere, where the Cluster array appears to move through the open field line region, initially in the northern lobe, then grazing the equatorial cusp boundary, and TC-1 appears to enter the magnetosheath after 

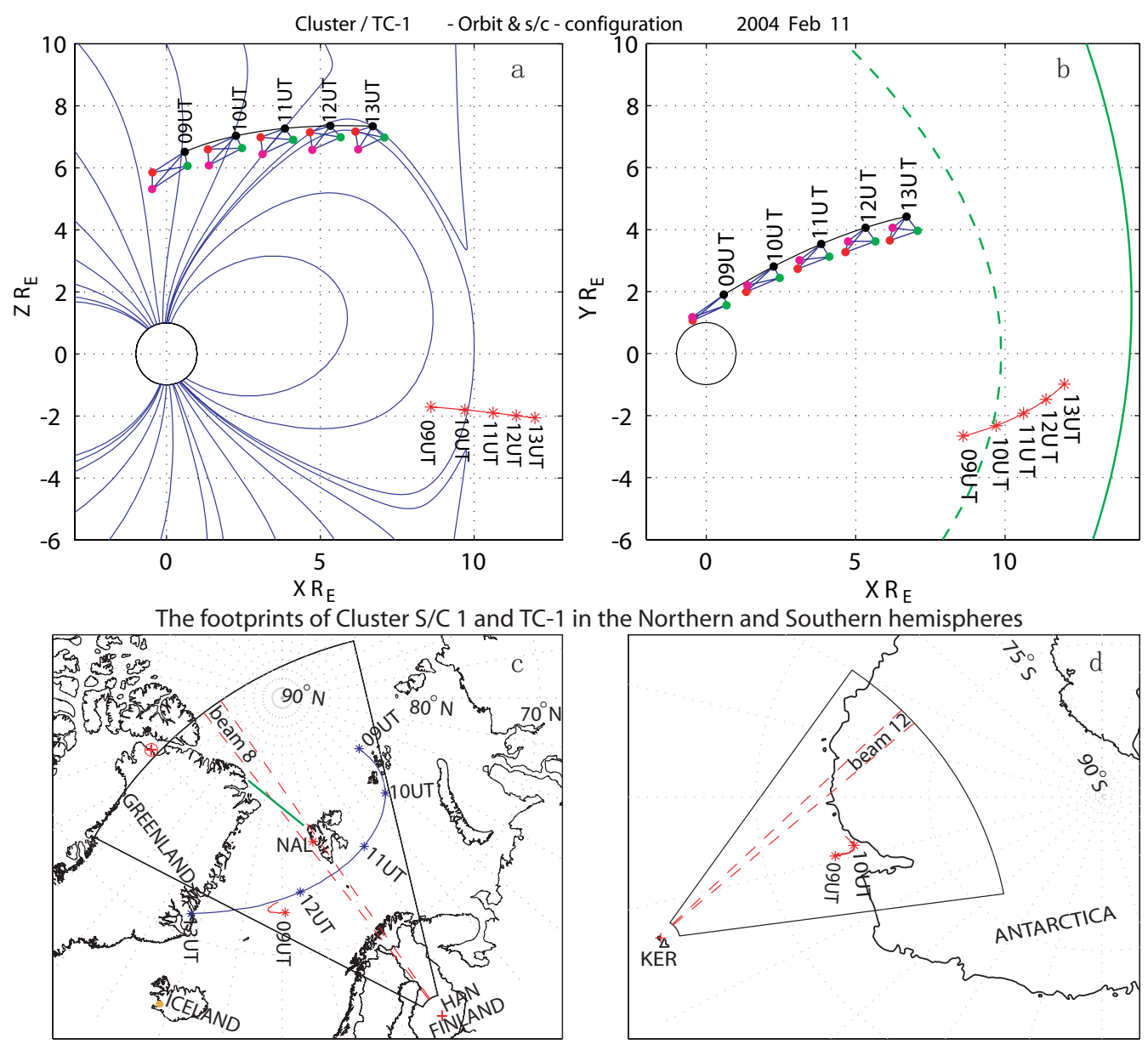

Fig. 2. All Cluster and TC-1 spacecraft tracks in the X-Z (a) and X-Y (b) plane in GSM coordinates, together with the ionospheric footprints of Cluster S/C 1 (blue line) and TC-1 spacecraft (red line) on the maps of Northern (c) and Southern (d) Hemispheres, between 09:00 and 13:00 UT on 11 February 2004. The orbit also shows the configuration of the Cluster spacecraft array as a tetrahedron (size scaled up by a factor of 20). The Model geomagnetic field lines are shown for the projection into the X-Z plane and cuts through the bow shock and magnetopause are shown for the $\mathrm{X}-\mathrm{Y}$ plane. The $\mathrm{X}-\mathrm{Z}$ plane field lines and ionospheric footprints of the spacecraft are drawn from the Tsyganenko '96 model inputting the real parameters. The field-of-view of the CUTLASS Finland radar and Kerguelen radar is presented as a fan in panels(c) and (d), respectively, with the beams employed in this study indicated by red dashed lines. The poleward-looking low elevation beam ( $32 \mathrm{M}$ dish) of ESR (between 76 and $85^{\circ}$ magnetic latitude) is indicated by the solid green line. The red" $\oplus$ " presents the magnetic pole.

about 10:00 UT. Thus there are no Cluster footprints in the Southern Hemisphere and TC-1 footprints end after about 10:00 UT in both hemispheres. In fact, the data shown below (see Fig. 3) indicate that Cluster exits into the magnetosheath earlier at $\sim 11: 20 \mathrm{UT}$ and TC- 1 exits at $\sim 09: 20 \mathrm{UT}$, which suggests a significantly eroded magnetopause at this time. The field-of-view of the CUTLASS Finland and Kerguelen SuperDARN radar is presented as a fan in Fig. 2c and $\mathrm{d}$, respectively, with the beam employed in this study indicated by red dashed lines. The poleward-looking low elevation beam (32M dish) of ESR (between 76 and $85^{\circ}$ magnetic latitude) is indicated by the solid green line in Fig. 2c. The red " $\oplus$ " represents the magnetic pole.

\subsection{Cluster and Double Star TC-1 observations}

Figure 3 plots in the top panels the magnetic field data from all 4 Cluster S/C (represented by black, red, green and magenta lines for the satellites $1,2,3,4$, respectively) for the interval of interest and from the TC- 1 spacecraft (blue line), together with the IMF clock angle, lagged by $69 \mathrm{~min}$ before 10:00 UT (lagged time) and $66 \mathrm{~min}$ after 10:00 UT (the convection time from ACE to subsolar magnetopause). The lower panels show the spectrograms of electron field-aligned differential energy flux from the HEEA and LEEA sensors of PEACE instrument on the Cluster S/C 1 and from the PEACE instrument on TC-1. It should be noted that the quasi-regular jumps in energy level in the TC-1 spectra (at 10:38, 10:58, 


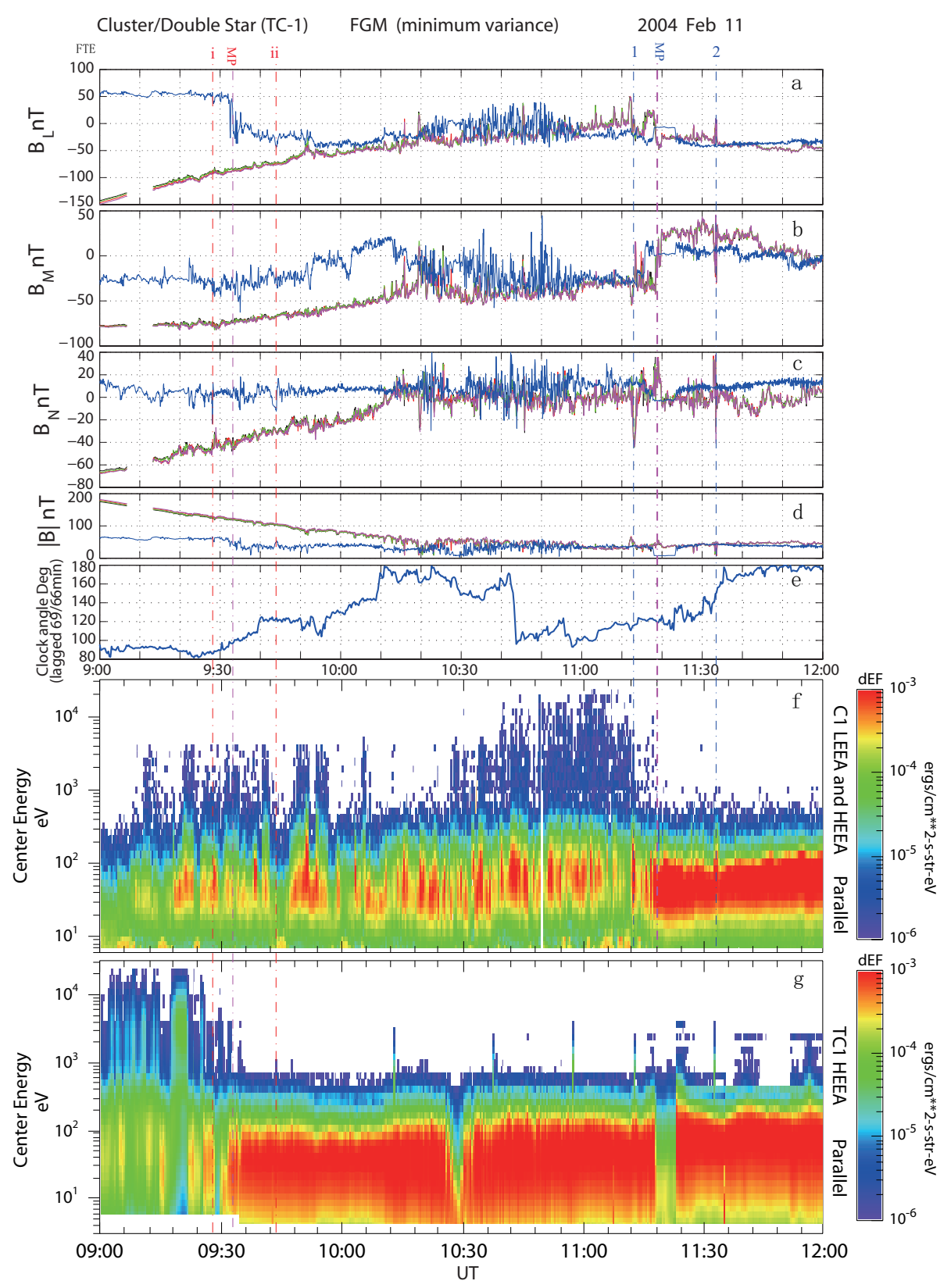

Fig. 3. An overview of the FGM measurements which are projected onto a LMN coordinates, and the lagged IMF clock angle, together with the spectrograms of electron field-aligned differential energy flux from the HEEA and LEEA sensor of PEACE on the Cluster S/C 1 and from PEACE instrument on TC-1, between 09:00 and 12:00 UT on 11 February 2004. Here highlight two FTEs observed by TC-1 by red dashed vertical lines, and two FTEs measured by Cluster by blue dashed vertical lines, respectively. There also marked the magnetopause crossing at about 09:33 UT for TC-1 and about 11:18 UT for Cluster by violet dashed vertical lines.

11:13, and 11:33 UT) are believed to be spacecraft generated interference spikes. The dropouts in the TC-1 distribution around 10:30 and 11:20 UT are excursions into the solar wind (encountering the bow shock), which is also clear from the TC-1 magnetic field (see Fig. 3), and it is clear that the second of these corresponds to the main magnetopause crossing by Cluster, suggesting a global compression of the magnetosphere and inward bow shock motion at this time.
The magnetic field data are expressed in local boundary normal coordinates (LMN), which have been found by performing minimum variance analysis (MVA) (Sonnerup and Scheible, 1998) on the local magnetopause crossing of Cluster S/C 3 between about 11:00 and 11:35 UT and of TC-1 between about 09:22 and 09:45 UT, to obtain the mean boundary normal $\boldsymbol{n}$ in each case, and unit vector $\boldsymbol{l}$ along the projection of the solar magnetospheric Z-direction perpendicular to 

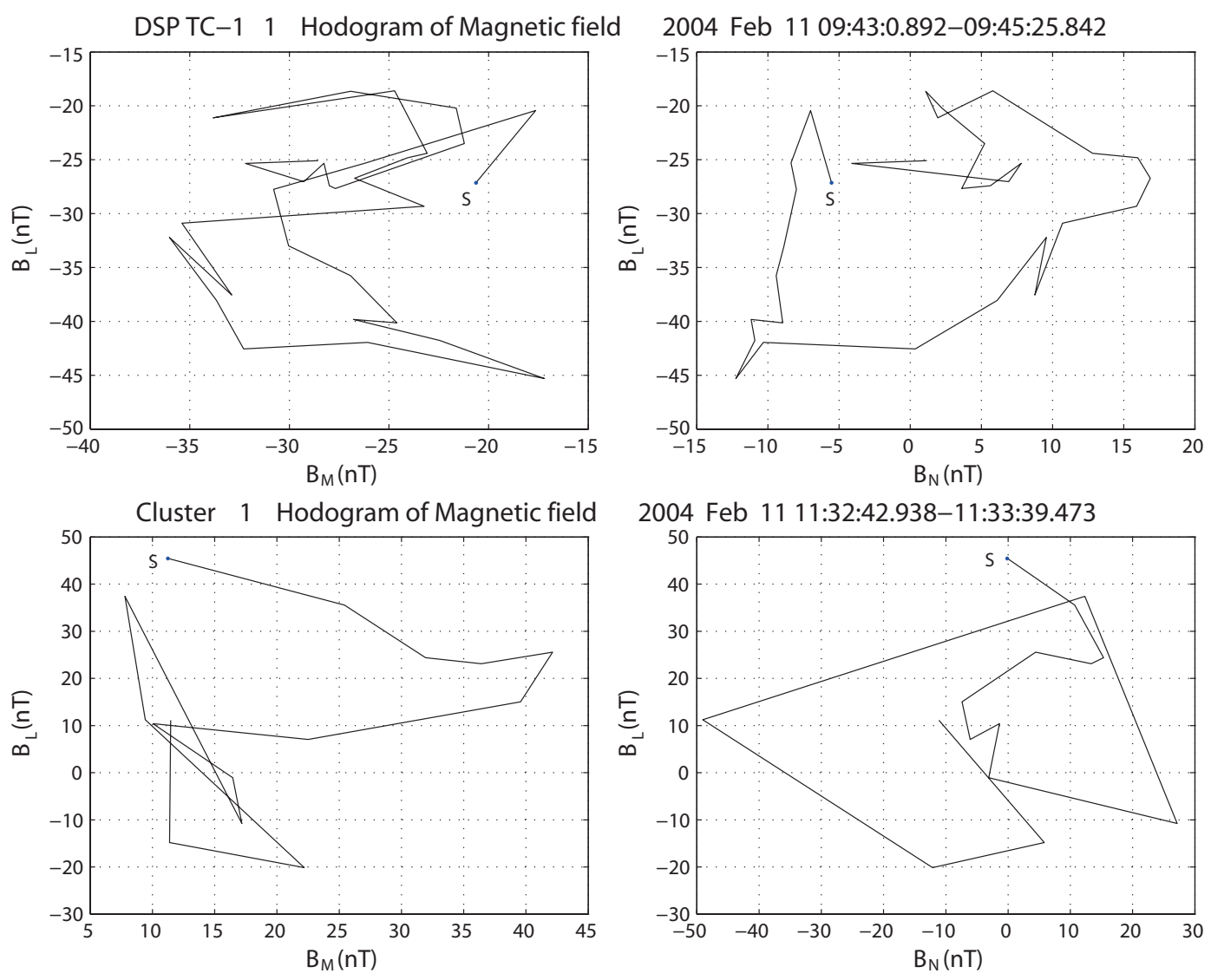

Fig. 4. Hodograms of the magnetic field in LMN coordinates for the periods 09:43:01-09:45:26 UT observed by TC-1 spacecraft and for the periods 11:32:43-11:33:39 UT measured by Cluster 1. Left and right panels show L-M and L-N representations. The black dot point (marked by "S") presents the start point in each panel.

the boundary normal. The unit vectors $\boldsymbol{l}, \boldsymbol{m}, \boldsymbol{n}$ are given as $(-0.40,0.40,0.83),(0.56,0.82,-0.12)$ and $(0.72,-0.42$, $0.55)$ in GSM coordinates, for the mean Cluster magnetopause crossing, and $(0.38,0.32,0.87),(0.09,0.92,-0.38)$ and $(0.92,-0.22,-0.31)$ in GSM coordinates, for TC- 1 . Inspection of the solar wind conditions shows that the IMF clock angle (see Fig. 3e) exhibited stable, dominant southward IMF conditions $\left(\mathrm{CA} \sim 130^{\circ}\right.$ to $180^{\circ}$ ) between about 09:54 and 10:43 UT and after 11:30 UT, and variable dominant dawnward IMF conditions (CA $\sim 80^{\circ}$ to $140^{\circ}$ ) with southward components before 09:54 UT and between 10:43 and 11:30 UT. This favours a high reconnection rate at the low-latitude magnetopause. Figure $3 \mathrm{a}$ and $\mathrm{f}$ shows disturbed magnetic field and precipating electron signatures, which indicates that the Cluster spacecraft were crossing open field line regions and cusp between about 09:10 and 11:12 UT and encountered the magnetopause at about 11:18 UT (marked by violet dashed vertical line in Fig. 3). The spacecraft were in the magnetosheath after about 11:18 UT. Figure $3 \mathrm{~g}$ shows the TC-1 spacecraft was moving outbound through the dayside, low-latitude magnetopause at about 09:33 UT and within the magnetosheath after that with two short ex- cursions into the solar wind. There are a large number of separate field parallel electron beams containing mixed highand low-energy electron populations in the Cluster S/C 1 electron spectrogram (Fig. 3f). There are a large number of electron beams in the TC-1 PEACE electron spectrograms (Fig. 3g), although these beams consists mostly of accelerated magnetosheath population. The small-scale electron signatures observed in the magnetosheath by TC-1 are quite complicated: some electron beams are very short and have high electron fluxes at $90 \mathrm{deg}$ pitch-angles. Some beams are longer and show reconnection-related signatures. These will be discussed later in the text in detail.

The electron distributions seen by all Cluster PEACE instruments between about 10:00 and 11:35 UT show clear mixing of magnetosheath and magnetospheric plasma populations, suggestive of reconnected flux tubes (FTEs) (Owen et al., 2001). In TC-1 PEACE measurements between about 09:00 and 10:45 UT the observed possible FTE structures do not show a clear mixing of plasma population from magnetospheric and magnetosheath sources. In order to identify FTEs, we have done hodogram analysis of the magnetic field variation for all of the FTE-like signatures observed 


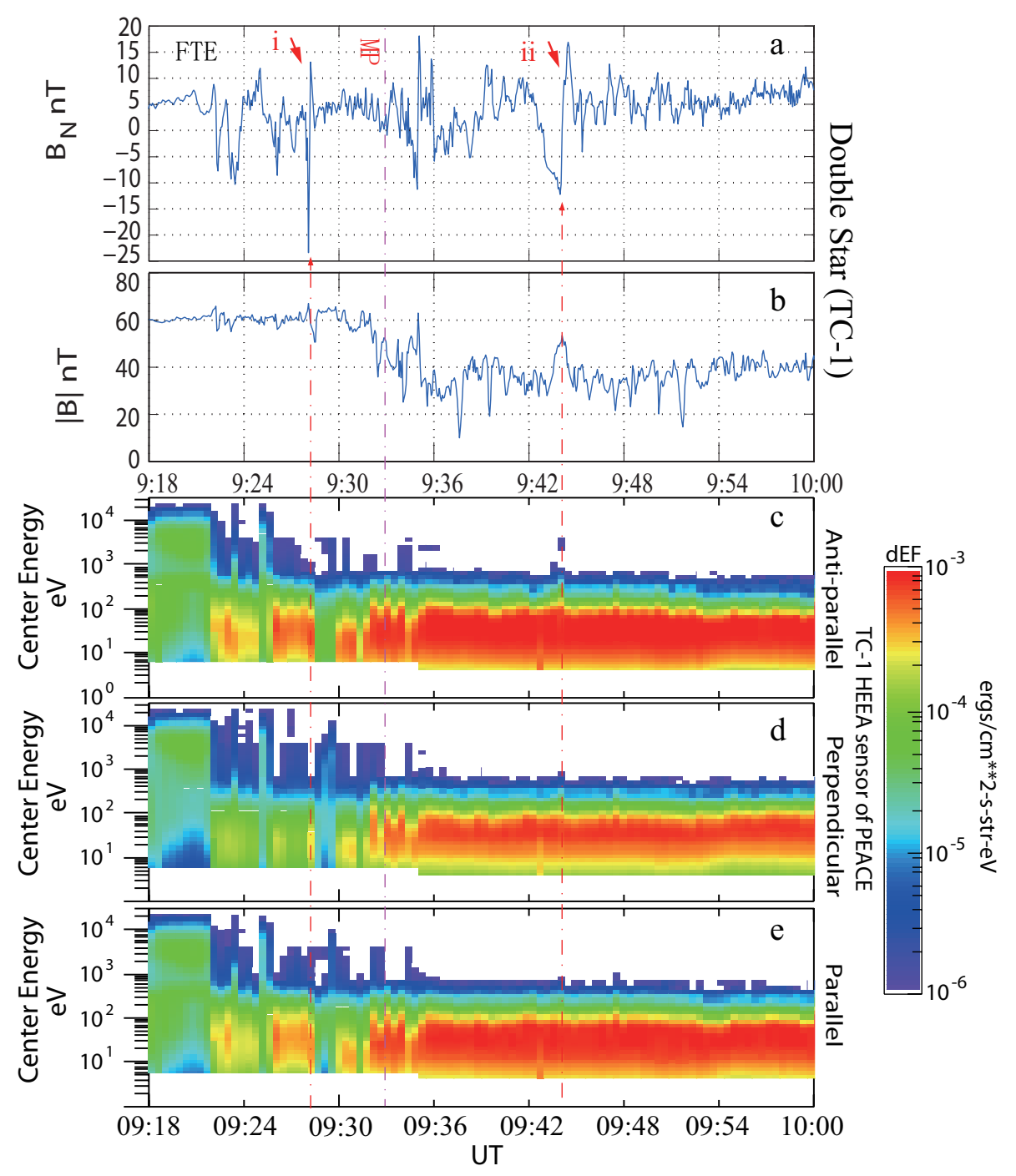

Fig. 5. Zoom in of the magnetic field boundary normal component $B_{\mathrm{N}}$ (same as Fig. 3c) and the field magnitude, together with PEACE electron spectrograms in anti-parallel, perpendicular, and parallel directions, observed by TC-1.

by Cluster and TC-1, respectively. As an example, Fig. 4 presents hodograms of the magnetic field in LMN coordinates for the periods 09:43:01-09:45:26 UT observed by TC1 spacecraft and for the periods 11:32:43-11:33:39 UT measured by Cluster S/C 1 . Left and right panels show L-M and $\mathrm{L}-\mathrm{N}$ representations. The black dot point (marked by "S") presents the start point in each panel. From Fig. 4, we find that there were clear "bump" of the reconnected flux tube in both L-M and L-N planes of the magnetic field crossed by TC- 1 and Cluster, respectively, which indicated that the FTE-like signatures are FTEs and could be thought as one of the criteria of the FTE identifications. According to the criterion from the hodogram analysis with higher plasma number density and velocity, we highlight for detailed analysis, one magnetospheric and one magnetosheath FTEs measured by TC-1 (indicated by red dashed vertical lines and marked by the red numbers "i-ii" at the top of Figs. 3 and 5), and two other FTEs observed by Cluster (indicated by blue dashed vertical lines and marked by the blue numbers " $1-2$ " at the top of Figs. 3 and 6), respectively. These data are plotted in Figs. 5 and 6 for interval of 09:18-10:00 UT for TC-1 and 11:00-12:00 UT for Cluster S/C 1 respectively to show more detail for the analysis below.

The panels in Fig. 5 show the magnetic field boundary normal component $B_{\mathrm{N}}$ (same as Fig. 3c) and the field magnitude, together with PEACE electron spectrograms in the anti-parallel, perpendicular, and parallel directions, as observed by TC-1. As in Fig. 3, we show two FTEs, observed by TC-1, by red dashed vertical lines. From Fig. 5 , we can find that near its magnetopause crossing, the TC- 1 spacecraft sampled a series of FTE signatures which are generally of large size and show the "reverse" polarity (negative/positive) 


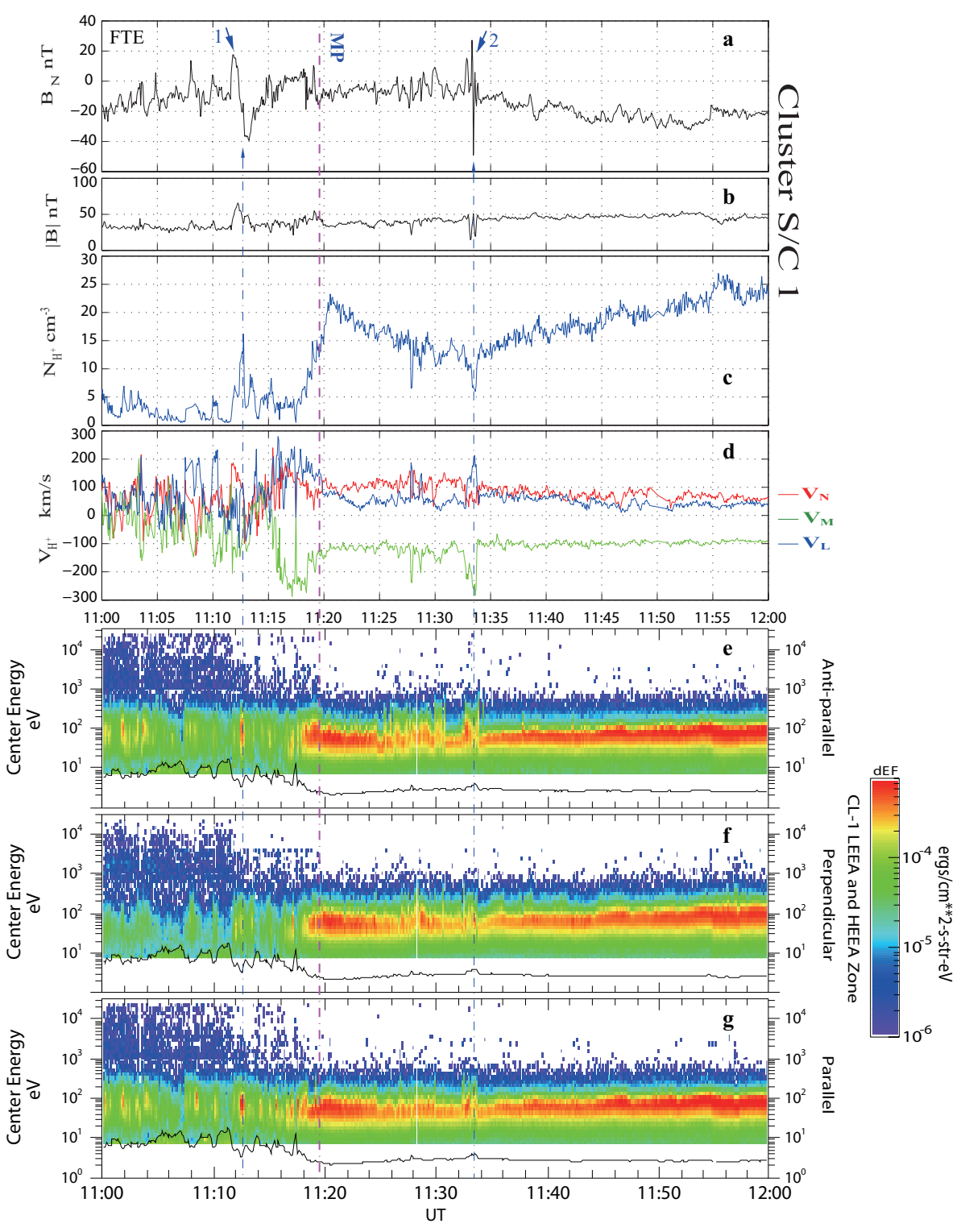

Fig. 6. Zoom in of (a) the magnetic field boundary normal component $B_{\mathrm{N}}$ (same as Fig. 3c), (b) the field magnitude, (c) the number density and (d) velocity (projected into LMN coordinates) of $\mathrm{H}^{+}$from CIS instrument onboard Cluster S/C 1, together with PEACE electron spectrograms in the (e) anti-parallel, (f) perpendicular, and (g) parallel directions, observed by Cluster S/C 1.

bipolar signatures in the $B_{\mathrm{N}}$ component (highlighted by the red dashed vertical lines and marked by the red numbers " $i-$ ii"). This suggests that TC- 1 observed southward moving flux tubes, which are connected to the southern cusp and were generated by low-latitude magnetic reconnection. The electron population was studied in detail for these two FTEs, using electron spectrogram and electron pitch-angle spectrogram (not shown here). The electron spectrogram shows the well-defined electron beam with accelerated magnetosheath plasma population mixed with the magnetospheric population for the second discussed FTE (ii). However there is no clear electron signature associated with the first FTE (i), as the electron beam does not show a classical mixing of the high energy magnetospheric population with the magnetosheath electrons. We suggest that the high energy electrons became less and less evident after the spacecraft crossed the magnetopause into the magnetosheath due to the fact that the spacecraft is crossing into the older opened flux tubes and that the magnetospheric electrons already escaped inside these tubes. Additionally, for the middle period shown in Fig. 3, between 10:20 and 11:00 UT, the TC-1 spacecraft observed very turbulent magnetic field. It revealed a small-scale sub-structure with many short-lived electron populations with mostly $90^{\circ}$ fluxes by analyzing the electron 
pitch-angle spectrogram (not shown here) for this period. We note that these observations are very similar to the observations presented by Retino et al. (2007) of the reconnection inside the turbulent magnetosheath. We suggest, as the TC-1 spacecraft lies deeper in the magnetosheath during this interval, that the observed magnetic field fluctuations and electron small scale sub-structure are not associated with FTEs, but with more complex processes which are out of scope of this paper.

In Fig. 6 we present (a) the magnetic field boundary normal component $B_{\mathrm{N}}$ (same as Fig. 3c), (b) the field magnitude, (c) the number density and (d) velocity (projected into LMN coordinates) of $\mathrm{H}^{+}$from CIS instrument onboard Cluster S/C 1, together with (e) the PEACE electron spectrograms in the (e) anti-parallel, (f) perpendicular, and (g) parallel directions, as observed by Cluster S/C 1 in the same way as Fig. 5. There are associated FTE signatures in the Cluster magnetic field data. As in Fig. 3, we indicate the two FTEs, observed by Cluster, by blue dashed vertical lines. All FTEs show standard polarity (positive/negative) bipolar signatures in the $B_{\mathrm{N}}$ component (see Fig. 6a) with enhanced $|B|$, enhanced number density of $\mathrm{H}^{+}$(decreased number density of $\mathrm{H}^{+}$in magnetosheath FTE) with fast ion flow in $\mathrm{L}$ and $\mathrm{M}$ direction (see Fig. 6c and d), and well defined electron beams, in which the plasma mainly focused on the parallel or anti-parallel directions, with a clear mixing of magnetosheath and magnetospheric plasma populations in the electron spectrograms for the first FTE and accelerated magnetosheath population for the second FTE (see Fig. 6e-i). This suggests that Cluster observed northward moving flux tubes, which are connected to the northern cusp and were generated by low-latitude magnetic reconnection. These FTE signatures become increasingly distinct and of larger size as the spacecraft cross the magnetopause into the magnetosheath. Additionally, for the earlier period shown in Fig. 3, between 09:00-10:00 UT, while Cluster was grazing the poleward cusp boundary, there appear to be a large number of often non-standard (positive/negative) FTE-like signatures. These therefore might represent a range of flux tube sizes (as discussed in Sect. 3). The electron spectrograms of Cluster S/C 1 also show clear mixing of magnetosheath and magnetospheric plasma population signatures suggestive of the reconnection features expected for each FTE.

\subsection{EISCAT measurements}

We now briefly examine the ionospheric dynamics which resulted from the FTEs discussed above.

Data from the two-dish incoherent scatter radar system near Longyearbyen, part of the EISCAT Svalbard Radars (ESR) (Wannberg et al., 1997) are used here. One dish (a $32 \mathrm{~m}$ parabolic antenna) is fully steerable towards any direction, and the other (a $42 \mathrm{~m}$ parabolic antenna) is fixed, pointing along the local magnetic field line. On the 11 February 2004 , the $32 \mathrm{~m}$-dish was pointing nearly towards geo- magnetic north (azimuth $336^{\circ}$ ), at low elevation $\left(30^{\circ}\right)$. The radars used alternating code measurement techniques to provide profiles of electron density, electron and ion temperature, and ion velocity along the line-of-sight.

During the interval of interest, the ionosphere above Svalbard was magnetically conjugate to Cluster and the radar measurements suggest that it was subject to impulsive precipitation associated with FTE-related bursts of magnetopause reconnection. Figure 7, for example, presents 2min post-integrations of the ESR radar observations between 09:00 and 12:00 UT (the same interval as in Fig. 3). Figure $7 \mathrm{a}$ presents observations of the electron density, the electron temperature, the ion temperature, and the line-of-sight ion velocity from the low elevation northward-directed ESR dish (azimuth $336^{\circ}$, elevation $30^{\circ}$ ). The post-integrated data are shown as a function of magnetic latitude between $76^{\circ}$ and $84^{\circ}$ and the observations cover the F-region altitude range from about 100 to $520 \mathrm{~km}$. The density measurements indicated a series of high-density plasma regions moving along the beam to higher latitudes (highlighted by the black solid lines in the first panel of Fig. 7a), so called poleward-moving plasma concentration enhancements, some of which could correspond, one-to-one to the FTEs observed by TC- 1 or Cluster. For example, the one highlighted by red arrow could correspond to the FTE 2 observed by Cluster. These events appeared quasi-periodically with a period of about $10 \mathrm{~min}$, which is roughly consistent with the period of FTEs observed by Cluster and TC-1 spacecraft. It is worth noting that the density measurements indicated a density of $3 \times 10^{11} \mathrm{~m}^{-3}$ between $79^{\circ}$ and $82^{\circ}$ geomagnetic latitude (see the first panel of Fig. 7a) in the events between about 10:10 and 11:10 UT and after about 11:42 UT. The electron temperature decreased in these events, highlighted by the black dashed bias lines (see the second panel of Fig. 7a). These suggest that the transient reconnection (FTE) leads to the erosion of the OCB equatorward to a region of higher density plasma (the solar EUV ionized plasma), followed by poleward relaxation of that boundary carrying with it the high density plasma accelerated into the polar flow (Lockwood and Carlson, 1992; Zhang et al., 2011). The plasma flow has a poleward component for most of the time between 09:00 UT and 12:00 UT (see the fourth panel of Fig. 7a, where positive represents flow away from the radar), except for some brief equatorward incursions before about 09:40 UT and after about 10:44 UT, which might be caused by the low or decrease in IMF clock angle (the dominant component of the IMF changes from negative $B_{\mathrm{Z}}$ to negative $B_{\mathrm{Y}}$ ). However, they did not show clear poleward moving channel-like structures accompany with the polar cap patches. This might be because ESR is located in the polar cap with the combined effect resulting from the tailward motion of the different separate flux tubes (FTEs) with different velocities. With the assumption that their poleward phase motion was roughly constant in speed (Lockwood et al., 2001), the black straight line can be mapped back to a magnetic latitude of about $76^{\circ}$, 


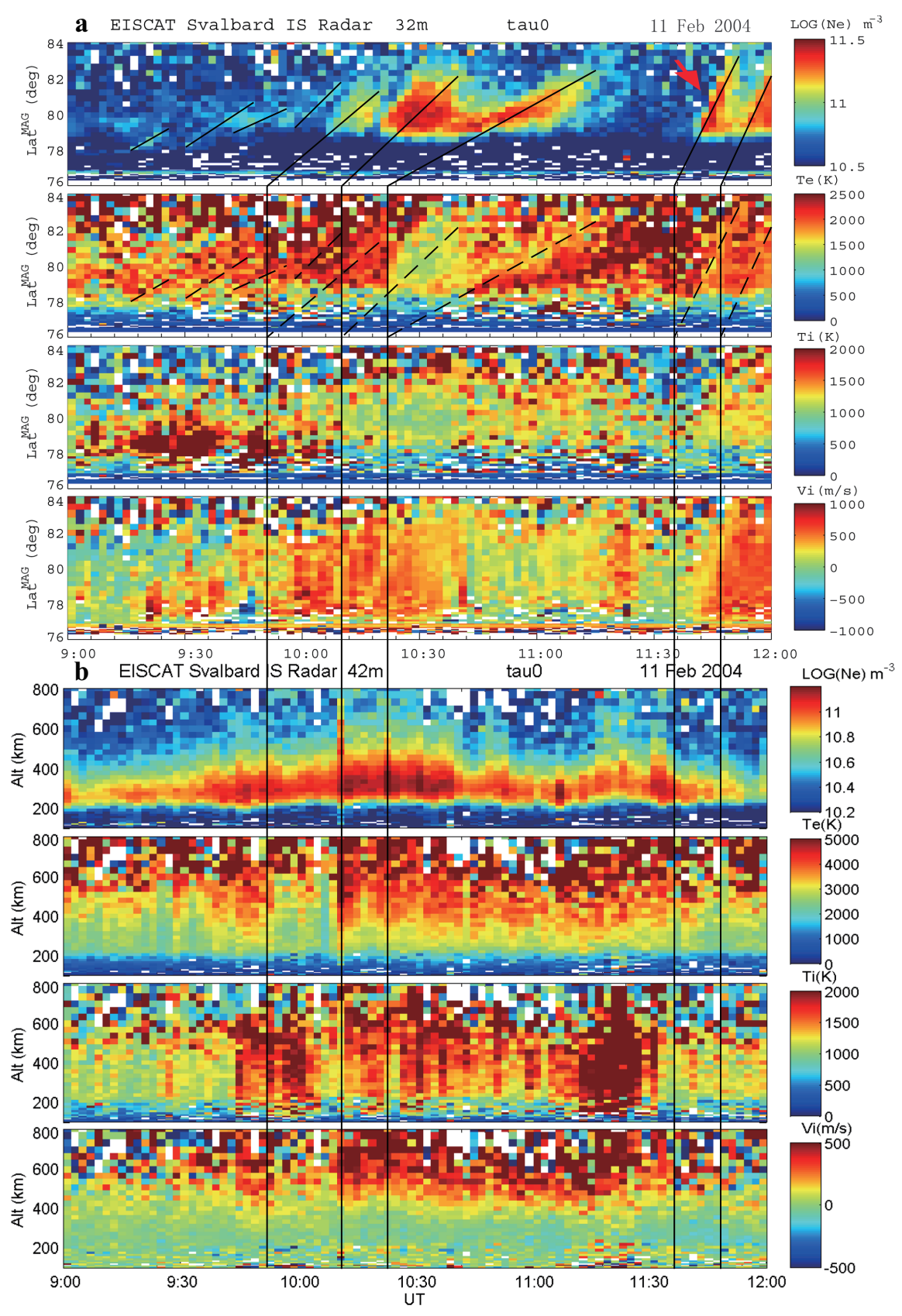

Fig. 7. Plasma parameters observed by the northward-directed ESR dish and the filed-aligned dish on 11 February 2004. From top to bottom: $N_{\mathrm{e}}$, electron density, $T_{\mathrm{e}}$, electron temperature, $T_{\mathrm{i}}$, ion temperature, and line of sight velocity, $V_{\mathrm{i}}$ (positive away from the radar) as a function of time and magnetic latitude (shorten as "Lat"MAG" in a) or altitude (shorten as "Alt" in b).

representing the location of the field-aligned ESR beam by black vertical lines.

Figure $7 \mathrm{~b}$ presents the same parameters from the fieldaligned ESR dish (azimuth $181^{\circ}$, elevation $81.6^{\circ}$ ), as a function of altitude between 100 to $800 \mathrm{~km}$. The electron density is high and well structured in the F-region, whereas the Eregion (between $95 \mathrm{~km}$ and $120 \mathrm{~km}$ ) looks empty. This again suggests the precipitation of low energy electrons. The low energy electrons are thought to be effective in heating the electron population in the ionosphere and, as a consequence, in triggering ion outflow (e.g. Pitout et al., 2002). The ion temperature shows many structures (see the third panel of Fig. 7b) and is a good indicator of the electric field (e.g. Pitout et al., 2002). There are many ion temperature/electric field enhancements which could reflect the large number of FTEs observed by Cluster. Due to the tailward motion of 

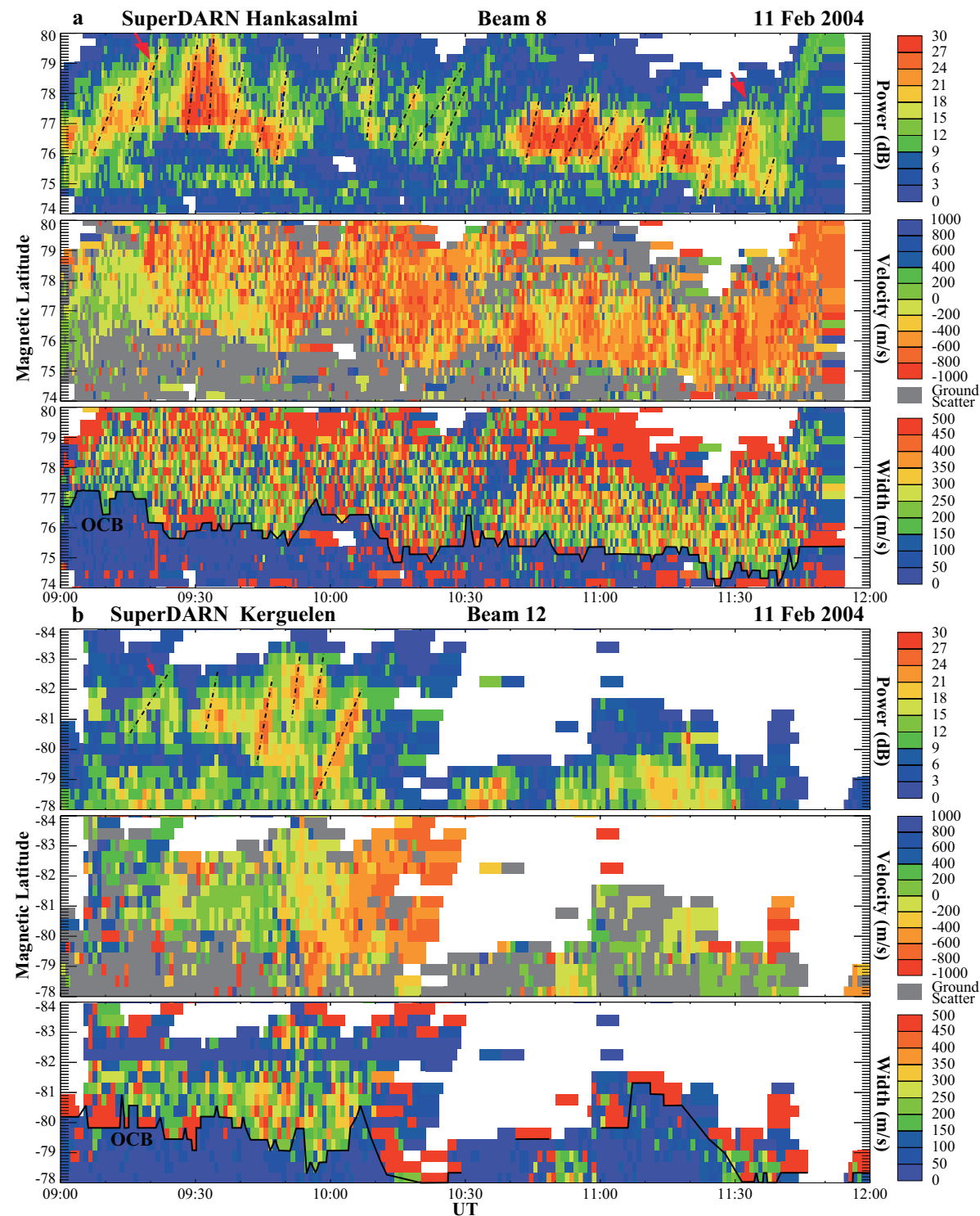

Fig. 8. Backscatter power, 1-o-s Doppler velocity, Doppler spectral measured by the (a) CUTLASS Finland and (b) Kergulen SuperDARN radar, respectively, during the period 09:00-12:00 UT on 11 February 2004.

the large number of separate flux tubes (FTEs) with different velocities produced by magnetic reconnection with a high reconnection rate as suggested by the Cluster observations, it is difficult to determine the direct ionospheric flow response to each FTE from the ESR radar data.

\subsection{SuperDARN observations}

The Co-operative UK, Twin Located Auroral Sounding System (CUTLASS) (Milan et al., 1997; Lester at al., 2004) is the easternmost pair of SuperDARN radars (Greenwald et al., 1995; Chisham et al., 2007) in the Northern Hemisphere. The SuperDARN radars normally measure the line-of-sight (l-o-s) Doppler velocity, spectral width, and the backscatter power from ionospheric plasma irregularities in 16 adjacent beam directions separated by $3.24^{\circ}$ in azimuth. A full scan is, therefore, completed in either $2 \mathrm{~min}$ or $1 \mathrm{~min}$, depending on the integration period along each beam, and covers $52^{\circ}$ in azimuth and over $3000 \mathrm{~km}$ in range with a resolution of $45 \mathrm{~km}$. The two CUTLASS radars have been upgraded such that two experimental modes can be run simultaneously, the so-called stereo capability (Lester et al., 2004). During the interval of interest, these two radars were running an experimental mode on channel B described in detail by Karhunen et al. (2006), with the normal scan, described above, on channel A. Only data from channel A are discussed in this paper. One of the CUTLASS radars located at Hankasalmi, Finland $\left(62.3^{\circ} \mathrm{N}\right.$, $26.6^{\circ} \mathrm{E}$ ) has a field of view as a fan covering the magnetic 
latitude between $65^{\circ}$ and $90^{\circ}$ including the directions of the ESR radars near Longyearbyen on Svalbard archipelago (see Fig. 2c), just discussed. The Kerguelen SuperDARN radar is located in Kerguelen island $\left(49.35^{\circ} \mathrm{S}, 70.26^{\circ} \mathrm{E}\right)$ in the Antarctic and looks to the magnetic south pole over a section of ionosphere that includes the east Antarctica ice cap and the southern ocean. The backscatter power, line-of-sight (1-o-s) Doppler velocity, and spectral width observed by the CUTLASS Finland radar in the Northern Hemisphere and Kerguelen radar in the Southern Hemisphere can be shown to examine the conjugate ionospheric response to the FTEs measured by Cluster and TC-1.

Figure 8 shows the backscatter power, 1-o-s Doppler velocity, and Doppler spectral, measured by the (a) CUTLASS Finland SuperDARN radar along beam 8 and (b) Kerguelen SuperDARN radar along beam 12 during the period 09:0012:00 UT on 11 February 2004, respectively. Polewardmoving regions of backscatter or enhanced backscatter power, known as "poleward-moving radar auroral forms" (PMRAFs), the radar counterpart of "poleward-moving auroral forms" (PMAFs), are often observed and are widely accepted to be the auroral signature of FTEs (e.g. Sandholt et al., 1990; Milan et al., 2000; Wild et al., 2001). Pinnock et al. (1995) and Provan et al. (1998) described the radar signatures of FTEs as "pulsed ionospheric flows" (PIFs), i.e. poleward-moving regions of enhanced convection flow in the dayside auroral zone. Depending on the exact nature of the convection response to transient reconnection, either PMRAFs (Milan et al., 2000) or PIFs (Provan et al., 1998), or both (Wild et al., 2001, 2003) can be observed by SuperDARN radars (Wild et al., 2001). In the present case, only PMRAFs were observed. During the interval of interest, the ionospheric footprints of Cluster and TC-1 along the magnetic field line (see Fig. 2c and d) are located in the fieldof-view of CUTLASS Finland radar in the Northern Hemisphere and Kerguelen radar in the Southern Hemisphere. Therefore, it is interesting to examine the CUTLASS and Kerguelen radars observations to check the conjugate ionospheric response to the FTEs observed by Cluster and TC- 1 .

In Fig. 8a and b, the backscatter power shows that there are a large number of clear PMRAFs in beam 8 of the Finland radar and a few clear PMRAFs in beam 12 of the Kerguelen radar, marked by the black dashed bias lines (see the first panel of Fig. 8a and b). Some of these could correspond, one-to-one to the FTEs observed by TC- 1 and/or Cluster, for example the PMRAFs highlighted by the red arrows in the first panel of Fig. 8a and b could correspond to the FTE i observed by TC-1 and FTE 2 measured by Cluster, respectively. The 1-o-s velocity suggests that the ionospheric convection is almost all anti-sunward flows (see the second panel of Fig. 8a and $b$ ), but there is lack of clearly PIFs. This is roughly consistent with the results reported by Milan et al. (2000) and also might be because of the combined effect of the tailward motion of the different separate flux tubes (FTEs) with different velocities. The wide values of the spectral width show clear equatorward extending cusp features observed by Finland radar between about 77 and $80^{\circ}$ at the beginning and about 74 and $79^{\circ}$ at the end (see the third panel of Fig. 8a) and observed by Kerguelen radar between -80 and $-84^{\circ}$ at the beginning and about -78 and $-82^{\circ}$ at the end (see the third panel of Fig. 8b), which can be taken as the further evidence of the FTEs resulting in strong ionospheric response in the cusp region. In comparison to Finland radar measurements in the Northern Hemisphere, however, the echoes received at Kerguelen radar were weaker (lower received signal power) and there are less PMRAFs observed by Kerguelen radar. This suggests that the nature of the backscatter observed in the northern and southern conjugate ionospheres were markedly different, which is consistent with the results reported by Wild et al. (2003). The open-closed boundary (OCB), shown by the black line in the third panel of Fig. 8a and $b$, corresponds to the Doppler spectral width boundary (Baker et al., 1995, 1997; Chisham et al., 2001, 2005). The OCB can be seen to have extended progressively equatorward, as the polar cap expanded due to magnetopause reconnection.

\section{Analysis of reconnection signatures}

\subsection{In situ tracking}

Since all 4 Cluster spacecraft sample the FTEs, we may apply four-spacecraft techniques (timing analysis (Russell et al., 1983; Harvey, 1998; Dunlop et al., 2001) and Spatiotemporal Difference (Shi et al., 2006)) to calculate the motion and scale of the FTEs observed by Cluster in each case using the tetrahedral spacecraft configuration. The results, briefly summarized in Table 1 , are almost similar and show that the motion of two FTEs at Cluster (the unit vectors $n_{\mathrm{GSM}}$ represent the direction of motion of the FTEs in GSM coordinate in the third row of Table 1) are mainly northeast. The speeds of these two FTEs are $100 \mathrm{~km} \mathrm{~s}^{-1}$ and $116 \mathrm{~km} \mathrm{~s}^{-1}$, repectively. These motions were also checked using deHoffmann-Teller (deH-T) analysis, which gives broadly similar directions and magnitudes. Assuming a cylindrical flux tube shape and according to $D_{\mathrm{FTEs}}=\boldsymbol{V} \cdot \Delta t$, the velocity and the duration of the whole bipolar signature ( $\sim 43 \mathrm{~s}$ and $80 \mathrm{~s}$ ) surrounding these two FTEs, gives estimated (maximum) flux tube sizes of $0.79 R_{\mathrm{E}}$ and $1.28 R_{\mathrm{E}}$. For TC-1, there are no ion data at this time so we may not directly estimate the flux tube speeds via deH-T analysis (but see later for the discussion of Table 1 showing the TC- 1 FTEs).

Although the effects of the magnetic field draping and the extension of the reconnection sites might be more complex than the prediction from the Cooling model (e.g. Shepherd et al., 1999), which examines the motion of reconnected magnetic flux tubes over the surface of the magnetopause (Cooling et al., 2001), in order to place the motion of the 

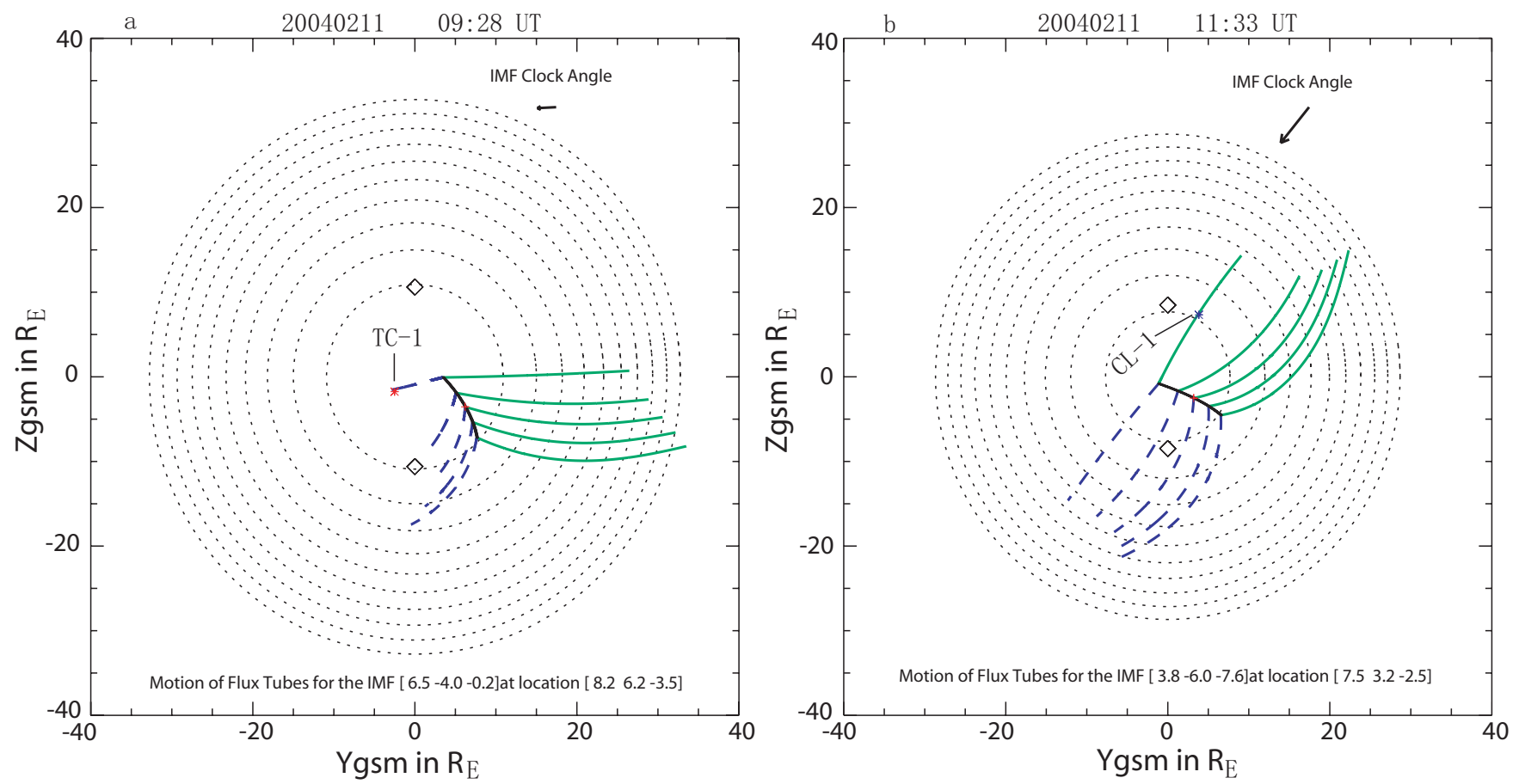

Fig. 9. Motion of reconnected flux tubes for low-latitude reconnection under IMF clock angle of (a) $85.63^{\circ}$ and (b) $148.13^{\circ}$, respectively, which is obtained by running the Cooling model. The reconnection conditions are satisfied along a merging line, the projection of which is indicated by the black diagonal line in the middle of the figure. The solid lines indicate the trajectories of tubes which connect to the northern cusp, and the dashed lines indicate those which connect to the southern cusp. The position of Cluster and TC-1 was represented by the blue and red star dot, respectively.

Table 1. Cataloge of Cluster FTE motion for the FTEs marked in Fig. 3, and the expected motion of the flux tubes by running the Cooling model and the angle between the expected velocities and the Cluster observations, together with the expected motion for the two FTEs measured by TC- 1 . The directions $(n)$ and the speeds $(|V|)$ of the motion are obtained from four-spacecraft techniques, and the size of each flux tube observed by Cluster was estimated by using the velocity and the duration of the whole bipolar signature of each FTE.

\begin{tabular}{cccccccc}
\hline FTEs & $\begin{array}{c}\text { UT_ } \\
\text { Cluster/TC-1 }\end{array}$ & $\begin{array}{c}n_{\text {GSM }} \\
(\text { motion) }\end{array}$ & $\begin{array}{c}|V| \\
\left.\mathrm{km} \mathrm{s}^{-1}\right)\end{array}$ & $\begin{array}{c}\text { Size } \\
\left(R_{\mathrm{E}}\right)\end{array}$ & $\begin{array}{c}\text { Expected } n_{\mathrm{GSM}} \\
(\text { motion) }\end{array}$ & $\begin{array}{c}\text { Expected }|V| \\
\left(\mathrm{km} \mathrm{s}^{-1}\right)\end{array}$ & $\begin{array}{c}\text { Angle } \\
\left({ }^{\circ}\right)\end{array}$ \\
\hline 1 & $11: 12: 30$ & $-0.80,0.55,0.26$ & 100.71 & 1.28 & $-0.75,0.21,0.62$ & 357.83 & 28.81 \\
2 & $11: 33: 26$ & $-0.84,0.27,0.45$ & 116.48 & 0.79 & $-0.72,0.40,0.57$ & 334.43 & 12.30 \\
i & $09: 28: 01$ & & & & $-0.28,-0.94,-0.19$ & 140.41 & \\
ii & $09: 44: 07$ & & & & $-0.41,-0.76,-0.51$ & 166.68 & \\
\hline
\end{tabular}

FTEs for simplification in context, the Cooling model has still been applied. As an example, Fig. 9 presents the motion of reconnected flux tubes for low-latitude reconnection, obtained by running the Cooling model under IMF clock angle of about $85^{\circ}$ (a) for TC-1 at about 09:28 UT (lagged time) and about $148^{\circ}$ (b) for Cluster at about 11:33 UT (lagged time). In Fig. 9a, the corresponding input parameters are: $N_{\mathrm{SW}}=7.12 \mathrm{~cm}^{-3}, V_{\mathrm{SW}}=368.13 \mathrm{~km} \mathrm{~s}^{-1}, B_{\mathrm{X}}=$ $6.50 \mathrm{nT}, B_{\mathrm{Y}}=-3.99 \mathrm{nT}, B_{\mathrm{Z}}=0.20 \mathrm{nT}, R_{\mathrm{BS}}=13.5 R_{\mathrm{E}}$, $R_{\mathrm{MP}}=10.61 R_{\mathrm{E}}$. In Fig. 9b, the corresponding input parameters are: $N_{\mathrm{SW}}=16.58 \mathrm{~cm}^{-3}, V_{\mathrm{SW}}=365.39 \mathrm{~km} \mathrm{~s}^{-1}, B_{\mathrm{X}}=$
$3.75 \mathrm{nT}, B_{\mathrm{Y}}=-6.02 \mathrm{nT}, B_{\mathrm{Z}}=-7.59 \mathrm{nT}, R_{\mathrm{BS}}=11.5 R_{\mathrm{E}}$, $R_{\mathrm{MP}}=8.48 R_{\mathrm{E}}$. Here, $N_{\mathrm{SW}}$ and $V_{\mathrm{SW}}$ present the solar wind number density and velocity, respectively; $B_{\mathrm{X}}, B_{\mathrm{Y}}, B_{\mathrm{Z}}$ are the three components of IMF in GSM coordinates, and $R_{\mathrm{BS}}$ and $R_{\mathrm{MP}}$ are the stand-off distance of bow shock and magnetopause, respectively. The view shows the YZ plane, looking earthward from the Sun. The dotted circles indicate the radius of the magnetopause at $\mathrm{X}$ coordinate intervals $5 R_{\mathrm{E}}$. The innermost circle represents $X=(1 / 2) R_{\mathrm{MP}}$ and contains the estimated position of the cusps (diamonds). In these figures, the expected merging line is indicated by the black tilted line 


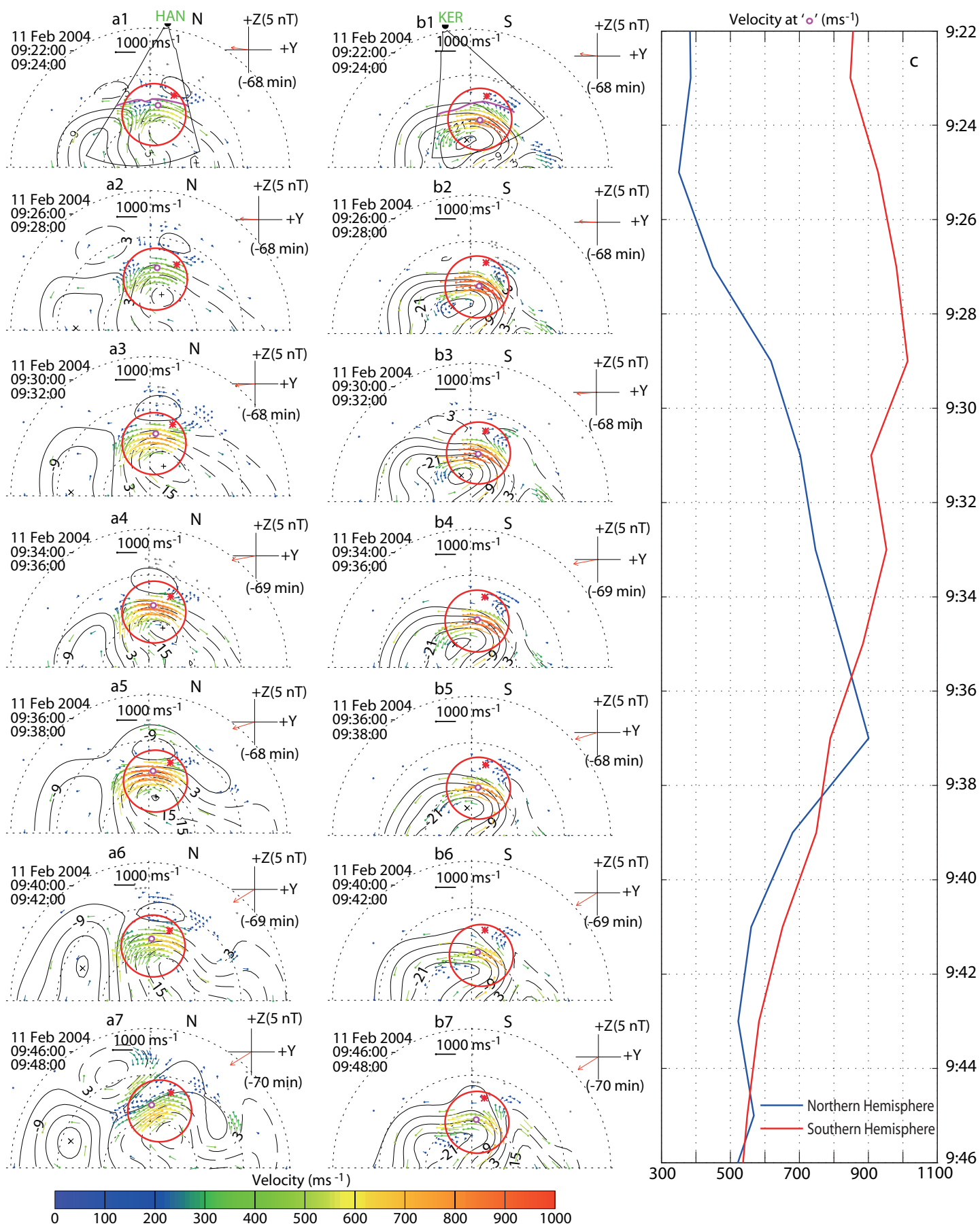

Fig. 10. Streamlines and vectors of the dayside ionospheric flows derived from the Northern (a1-7 and d1-6) and Southern (b1-7 and e1-7) Hemispheric SuperDARN velocity measurements shown on geomagnetic grids, obtained from the "map potential" algorithm. Maps are shown for (a) from 09:22 to 09:46 UT and for (b) from 11:18 to 11:48 UT. The field-of-view of the CUTLASS Finland radars (HAN) and Kerguelen radar (KER) are presented as a fan in panel a1 (d1) and b1 (e1), respectively. The direction and magnitude of the lagged IMF are indicated at the right-hand upper corner of each map. The red star and blue circle represents the ionospheric footprint of TC-1 (in panels a1-7 and b1-7) and Cluster S/C 1 (in panels c1-6), respectively. The time series of ionospheric flow velocity, which are extracted from the convection maps at the violet circle in panels (a) and (b) and the violet rhombus in panels (d) and (e), are presented in panels (c) and (f), respectively. 


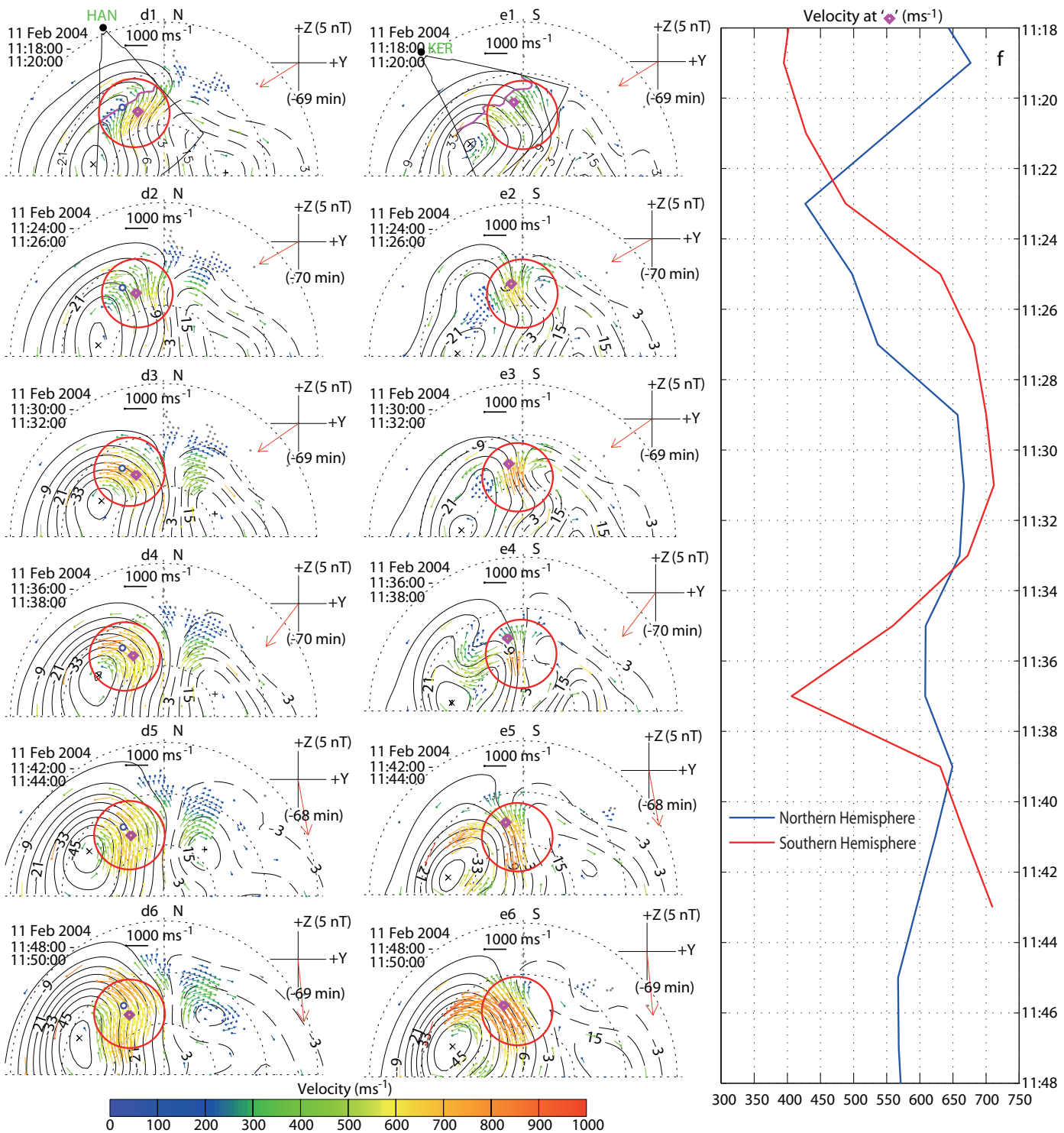

Fig. 10. Continued.

Table 2. The IMF and solar wind conditions at the core time of FTE i observed by TC-1 and the FTE 6 measured by Cluster on 11 February 2004, and of the 12:31 UT FTE and 12:51 UT FTE on 1 April 2004 (reported by Zhang et al., 2008).

\begin{tabular}{lrrrrrr}
\hline \multirow{2}{*}{ IMF and Solar Wind } & \multicolumn{2}{c}{ FTEs on 11 February 2004 } & & \multicolumn{2}{c}{ FTEs on 1 April 2004 } \\
\cline { 2 - 3 } \cline { 5 - 6 } & FTE $\mathrm{i}$ & FTE 6 & & 12:31 UT FTE & 12:51 UT FTE \\
\hline$B_{\mathrm{X}}(\mathrm{nT})$ & 6.3 & 3.9 & & -2.6 & -2.4 \\
$B_{\mathrm{Y}}(\mathrm{nT})$ & -4.1 & -4.5 & & 2.2 & 3.2 \\
$B_{\mathrm{Z}}(\mathrm{nT})$ & -0.6 & -9.3 & & -2.5 & -1.4 \\
Clock Angle $\left({ }^{\circ}\right)$ & 94.4 & 154.4 & & 138.7 & 108.7 \\
Elevation Angle $\left({ }^{\circ}\right)$ & -84.6 & -22.7 & & 46.1 & 59.7 \\
Cone Angle $\left(^{\circ}\right)$ & 33.3 & 69.3 & & 128.0 & 124.5 \\
$V_{\mathrm{SW}}\left(\mathrm{km} \mathrm{s}^{-1}\right)$ & 368.6 & 369.4 & & 423.0 & 423.7 \\
\hline
\end{tabular}


in the middle of the figure, where its length has been limited to an arbitrary maximum of $10 R_{\mathrm{E}}$ and the model allows the position relative to the subsolar point to be chosen. Pairs of open reconnected flux tubes are assumed to be initiated along the merging line and are followed over a period of $600 \mathrm{~s}$, resulting in the fan of motion tracks shown. The trajectories of flux tubes which connect to the northern cusp are indicated by the solid lines and the dashed lines indicate those which connect to the southern cusp. The positions of TC-1 and Cluster S/C 1 are represented by the red and blue star dots in Fig. 9a and b, respectively. It is clear from the changing IMF direction that both spacecraft may observe a variety of FTE motions depending on the different IMF conditions, which agrees well with the results of Dunlop et al. (2005) and Zhang et al. (2008).

We show the expected velocities of the flux tubes near the spacecraft corresponding to the two FTEs observed by Cluster and the angle between the expected (Cooling) velocities and the Cluster observations in Table 1. These results demonstrate that the expected motion is mainly northeast. The speeds of the expected flux tubes are $\sim 358 \mathrm{~km} \mathrm{~s}^{-1}$ and $334 \mathrm{~km} \mathrm{~s}^{-1}$, and the angles are all less than $30^{\circ}$. This suggests that the direction of motion of the expected flux tube are relatively consistent with that of the FTEs observed by Cluster, but the predicted speeds are a factor of two to three times higher than the Cluster observations, which is roughly consistent with the statistical results of Fear et al. (2007). This might also be caused by the following two reasons. Firstly, the velocity derived from the four-spacecraft techniques is the velocity of the FTE perpendicular to the flux tube, and the axis is assumed to extend infinitely, so motion along the FTE axis cannot be estimated. Secondly, the motion of a flux tube branch at positions further from the point at which it threads the magnetopause may be more influenced by local magnetosheath flows (Fear et al., 2007). The expected (Cooling) velocities of the flux tubes, corresponding to TC-1 observations, are also presented in Table 1, and show that the expected motion is southwest. The speeds of the expected flux tubes are $\sim 140 \mathrm{~km} \mathrm{~s}^{-1}$ and $167 \mathrm{~km} \mathrm{~s}^{-1}$, respectively.

\subsection{Ionospheric convection}

The motion of individual flux tubes may be expected to correspond to the local motion in the ionospheric flow cells at their footprints and it is interesting to briefly examine the global ionospheric convection observed by SuperDARN radars in both hemispheres in this context, which will help us to understand how the high-latitude ionospheric convection responds to a change in reconnection rate and/or location such as it occurs when a change in the IMF orientation impacts the magnetopause. We therefore present the two minute averaged dayside ionospheric convection patterns observed by the SuperDARN radar in Fig. 10. An increasing clock angle should result in an ionospheric convection flow enhancement (Lockwood et al., 2003) and the observed flow cells show sensitivity to the IMF orientation in this sequence also.

The SuperDARN radars also provide a unique way to directly monitor two-dimensional convection in the highlatitude ionosphere on a global scale. We therefore also present the ionospheric convection patterns with the map potential plots, derived by using the technique of Ruohoniemi and Baker (1998), observed by nine of the Northern Hemisphere radars and four of the Southern Hemisphere radars during the interval of interest.

The panels in Fig. 10 show successive flow maps for the Northern and Southern Hemisphere from 09:22 to 09:46 UT (a1-7 and b1-7) and from 11:18 to 11:48 UT (d1-6 and e16 ), in order to correspond closely to the highlighted FTE i observed by TC- 1 and FTE 2 measured by Cluster, respectively. The dashed concentric circles indicate lines of constant magnetic latitude in $10^{\circ}$ increments and noon is located at the top of each plot. The cross-hair axis inset at the top right of each plot shows the IMF $B_{\mathrm{Y}}$ and $B_{\mathrm{Z}}$ components as a red arrow, where the time delay from ACE to the ionosphere is also indicated. The red circle highlights the region of velocity enhancement, as indicated by increased lengths of color drift vectors. The red star and blue circle represents the ionospheric footprint of TC-1 (in Fig. 10a1-7 and Fig. 10b17) and of Cluster S/C 1 (in Fig. 10d1-6), respectively. The field-of-view of the CUTLASS Finland radars (HAN) and Kerguelen radar (KER) is presented as a fan in Fig. 10a1 (d1) and b1 (e1), respectively. The violet line in each fan represents the open-closed boundary (OCB), marked by the Doppler spectral width boundary from each beam (Baker et al., 1995, 1997; Chisham et al., 2001, 2005). We note that the footprint of TC-1 or Cluster lie slightly equatorward of the OCB and are out of the flow burst region. This is because the TC- 1 or Cluster position lies on magnetospheric field lines computed from the Tsyganenko' 96 model, rather than at the boundary, and therefore that the computed footprints lie slightly equatorward of the likely true locations. These points suggest that these FTEs have motions, which reflect the likely flow directions at the respective poleward positions of their footprints (e.g. the position at the violet circle in Fig. 10a and b and the violet rhombus in Fig. 10d and e). The convection cell pattern implies a relatively direct global context for the evolution of the sampled FTEs. The time series of ionospheric flow velocity, which are extracted from the convection maps at the violet circle in Fig. 10a and $\mathrm{b}$ and the violet rhombus in Fig. 10d and e, are presented in Fig. 10c and f, respectively, where the time is selected the middle time of each pattern.

From Fig. 10c and f, we find that there are very clear velocity enhancements from 09:25 to 09:43 UT and from 11:23 to 11:45 UT for the flow at the violet circle (or rhombus) in the Northern Hemisphere, and from 09:23 to 09:45 UT and from 11:19 to 11:37 UT for the flow at the violet circle (or rhombus) in the Southern Hemisphere. These demonstrate there are clear velocity enhancements at the near-noon, high-latitude sector of the morning cell or afternoon cell in 
the Northern and Southern Hemisphere in Fig. 10 (a2-6 and b2-6, morning cell) and in Fig. 10 (d2-5 and e2-4, afternoon cell). The velocity enhancements lasted about 18-22 min for both the FTE i observed by TC- 1 and the FTE 2 measured by Cluster, which might suggest that the evolution time of FTEs is about $18-22 \mathrm{~min}$ from their origin on magnetopause (at reconnection site) to their addition to the magnetotail lobe. These are roughly consistent with the expected ionospheric flow excitation and decay time scale of 10-15 min (Cowley and Lockwood, 1992). These correspond to the ionospheric response to the FTE $i$ observed by TC- 1 and FTE 2 measured by Cluster. Near the positions of the violet circle, the drift vectors are mainly in westward (eastward) in the Southern (Northern) Hemisphere, in a good agreement with the expectations from the Cooling analysis; and near the violet rhombus, the drift vectors are mainly in northward to northeast in the Northern Hemisphere, also in a good agreement with the expectations from the Cooling analysis and the Cluster observations. The correspondence with the convection signatures confirms that individual flux tube movements are consistent with the anti-sunward ionospheric convections in the cusp regions of both hemispheres, and therefore are consistent with the two-dimensional (2-D) reconnection pulse model (Saunders et al., 1983; Southwood et al., 1988), where the model explains the bulge as the effect of a pulse of enhanced reconnection rate at an X-line whose length is not specified and allows for longitudinal event elongation. As this model prediction, the footprint of the newly opened flux tube moves along the streamlines in the distorted "two-cell" convection pattern, and the ionospheric signatures of these events show that patches of newly opened flux, produced by successive reconnection pulses, are appended to each other in a contiguous manner, causing discontinuous steps in the cusp ion dispersion on the boundaries between poleward moving events (Lockwood and Hapgood, 1998). This correspondence (with the conjugate response) confirms the interpretation from the analysis in Sect. 2, despite the lack of direct one-to-one identifications with the ionospheric FTE signatures. These comparisons further suggest the formation of an extensive, low latitude merging line, with a reconnection geometry reflected in the observed FTE motion.

Comparing the ionospheric convections in both hemispheres, we find the velocity enhancements starting from 09:25 and 11:23 UT in the Northern Hemisphere and from 09:23 and 11:19 UT in the Southern Hemisphere for the FTE $i$ observed by TC- 1 and the FTE 2 measured by Cluster, respectively, which suggests the ionospheric response time in the Northern Hemisphere is 2 min later for the FTE i observed by TC- 1 and 4 min later for the FTE 2 measured by Cluster than in the Southern Hemisphere. Does this suggest the reconnection site is located southward of the subsolar region? This might need better data coverage in the Southern Hemisphere to show the further evidence or be because of a different conductivity in the northern and southern highlatitude ionosphere. Whilst the intensities of the ionospheric convections are much stronger in the Southern Hemisphere than in the Northern Hemisphere for FTE i under the conditions of smaller IMF clock angles $\left(\sim 94.4^{\circ}\right.$, see in Table 2 and Fig. 10a), they are stronger in the Northern Hemisphere than in the Southern Hemisphere for FTE 2 under the conditions of larger IMF clock angles $\left(\sim 154.4^{\circ}\right.$, see in Table 2 and Fig. 10b). This might lead to an unclear developing and fading of the velocity enhancement in the ionosphere of the more intense hemisphere because of the stronger background and suggests that the asymmetry of the intensities of the ionospheric convections between the Northern and Southern Hemisphere are IMF clock angle dependent. The convection signatures therefore show that there is a good response to the IMF conditions resulting in clear anti-sunward ionospheric convections at the cusp regions of both hemispheres, consistent with the onset of low-latitude reconnection and a predominantly eastward IMF. The velocity enhancements of the ionospheric convections, corresponding to the other FTEs, show the similar character, although they are not so strong and clear.

It is worth noting that the implied evolution time of these FTEs are different with the results reported by our previous paper (Zhang et al., 2008), but the response time of these FTEs are similar. That paper showed that the implied evolution time of the FTEs was about 4-6 min from its origin on magnetopause (at reconnection site) to its addition to the polar cap (the magnetotail lobe), and the ionospheric response time in the Southern Hemisphere were 26 min longer than that in the Northern Hemisphere for the events on 1 April 2004. This might be because of the dayside magnetopause reconnection occurred at the different hemisphere and the FTEs had different speed under the different IMF and solar wind conditions (see Table 2). From Table 2, we can find that for the two FTEs on 11 February 2004 , the IMF had negative $B_{\mathrm{Y}}$ and $B_{\mathrm{Z}}$ with a positive $B_{\mathrm{X}}$ component, giving a negative elevation angle (elevation angle $\left.=\left(B_{\mathrm{X}} /\left|B_{\mathrm{X}}\right|\right) \tan ^{-1}\left(\left|B_{\mathrm{X}}\right| / B_{\mathrm{Z}}\right)\right)$ and a smaller cone angle (cone angles $=\cos ^{-1}\left(B_{\mathrm{X}} /|B|\right)$ ); for the two FTEs on 1 April 2004 (reported by Zhang et al., 2008), the IMF had negative $B_{\mathrm{X}}$ and $B_{\mathrm{Z}}$ with a positive $B_{\mathrm{Y}}$ component, giving a positive elevation angle and a larger cone angle. Considering the topology of Earth magnetic field during each event, the negative (positive) elevation angle and/or smaller (larger) cone angle with a negative (positive) $B_{\mathrm{Y}}$ component may suggest the reconnection site is located southward (northward) of the subsolar region. This is because the first contact point between IMF and Earth's magnetic field at dayside magnetopause (largest shear angle point) will be located at southward (northward) of the subsolar region when the IMF $B_{X}$ component is positive (negative) with a negative $B_{\mathrm{Z}}$. The solar wind speeds are smaller for the two events on 11 February 2004 than that for the two events on 1 April 2004, which may lead to the implied evolution times for the FTEs on 11 February 2004 are longer than that for the FTEs on 1 April 2004. 


\section{Summary}

In summary, we have presented the features of two FTEs observed by TC- 1 and two FTEs measured by Cluster, while the Cluster array was near the high-latitude magnetopause and the TC-1 spacecraft was near the subsolar magnetopause. The ionospheric plasma flow and convection analysis, which are simultaneously observed by the ESR and CUTLASS Finland and Kerguelen SuperDARN radar, and conjugate observed by the SuperDARN radars, are also presented and support well the in-situ observations. Using the Cluster 4spacecraft observations, we calculated the velocity and the size of the flux tubes. The inferred northwardly (southwardly) reconnected flux tubes for these FTEs are shown to move northward (southward) or north-east (south-west) and tailward, either with dominant northward (southward) or dominant eastward (westward) velocity components under the stable IMF and high clock angle conditions. Under the unstable IMF and low clock angle conditions the motion is more eastward (westward). The FTE motion is consistent with the expected motion of reconnected magnetic flux tubes over the surface of the magnetopause, arising from a predominantly subsolar reconnection site during the prevailing IMF and solar wind conditions. The simultaneous ESR measurements recorded poleward flow and the CUTLASS Finland and Kerguelen SuperDARN radar observations showed the "poleward-moving radar auroral forms" (PMRAFs), indicative of bursty reconnection at the subsolar region of magnetopause and the simultaneous and conjugate SuperDARN observations show that flux tube motion is consistent with global conjugate ionospheric convections in both hemispheres. The flux tube footprints map to clear positions in a predominantly two-cell convection pattern, which are temporally correlated with the local ionospheric flow enhancements at these positions. The time durations of the velocity enhancements in the both hemispheres might imply that the evolution time of FTEs is about 18-22 min from their origin on magnetopause (at reconnection site) to their addition to the magnetotail lobe. However, the ionospheric response time in the Northern Hemisphere is 2 and $4 \mathrm{~min}$ longer than the response time in the Southern Hemisphere, for the FTE i observed by TC-1 and the FTE 2 measured by Cluster, respectively.

Acknowledgements. This work is supported by the National Natural Science Foundation of China (grant No. 41104091, 41031064, 40890164, 40974083), the Natural Science Foundation of Shanghai, China (grant No. 11ZR1441200), the Youth Scientific and Technological Innovation Foundation, Polar Research Institute of China (No. JDQ201001) and Ocean Public Welfare Scientific Research Project, State Oceanic Administration People's Republic of China (No. 201005017). M. W. Dunlop is partly supported by Chinese Academy of Sciences (CAS) visiting Professorship for senior international scientists (Grant No. 2009S1-54). M. Lester is supported by STFC grant ST/H002480/1. We acknowledge the NASA CDAWeb site to supply us the solar wind and IMF data from the
ACE spacecraft. We thank the Cluster/Double Star Operations Teams, the Cluster FGM PI, E. A. Lucek and the TC-1 FGM PI C. M. Carr for the magnetic field data, the Cluster/Double Star PEACE PI A. N. Fazakerley, for the electron spectrometer data, and the Cluster CIS PI H. Rème, for the ions data.

Guest Editor A. Masson thanks two anonymous referees for their help in evaluating this paper.

\section{References}

Amm, O., Donovan, E. F., Frey, H., Lester, M., Nakamura, R., Wild, J. A., Aikio, A., Dunlop, M., Kauristie, K., Marchaudon, A., McCrea, I. W., Opgenoorth, H.-J., and Strømme, A.: Coordinated studies of the geospace environment using Cluster, satellite and ground-based data: an interim review, Ann. Geophys., 23, 2129_ 2170, doi:10.5194/angeo-23-2129-2005, 2005.

Balogh, A., Carr, C. M., Acuña, M. H., Dunlop, M. W., Beek, T. J., Brown, P., Fornacon, K.-H., Georgescu, E., Glassmeier, K.H., Harris, J., Musmann, G., Oddy, T., and Schwingenschuh, K.: The Cluster Magnetic Field Investigation: overview of in-flight performance and initial results, Ann. Geophys., 19, 1207-1217, doi:10.5194/angeo-19-1207-2001, 2001.

Baker, K. B., Dudeney, J. R., Greenwald, R. A., Pinnock, M., Newell, P. T., Rodger, A. S., Mattin, N., and Meng, C.-I.: HF radar signatures of the cusp and low-latitude boundary layer, J. Geophys. Res., 100, 7671-7695, 1995.

Baker, K. B., Rodger, A. S., and Lu, G.: HF-radar observations of the dayside magnetic merging rate: A Geospace Environment Modeling boundary layer campaign study, J. Geophys. Res., 102, 9603-9617, 1997.

Berchem, J. and Russell, C. T.: Flux transfer events on the magnetopause: Spatial distribution and controlling factors, J. Geophys. Res., 89, 6689-6703, 1984.

Carr, C., Brown, P., Zhang, T. L., Gloag, J., Horbury, T., Lucek, E., Magnes, W., O’Brien, H., Oddy, T., Auster, U., Austin, P., Aydogar, O., Balogh, A., Baumjohann, W., Beek, T., Eichelberger, H., Fornacon, K.-H., Georgescu, E., Glassmeier, K.-H., Ludlam, M., Nakamura, R., and Richter, I.: The Double Star magnetic field investigation: instrument design, performance and highlights of the first year's observations, Ann. Geophys., 23, 27132732, doi:10.5194/angeo-23-2713-2005, 2005.

Chisham, G., Pinnock, M., and Rodger, A. S.: The response of the HF radar spectral width boundary to a switch in the IMF By direction: Ionospheric consequences of transient dayside reconnection? J. Geophys. Res., 106, 191-202, 2001.

Chisham, G., Freeman, M. P., Sotirelis, T., Greenwald, R. A., Lester, M., and Villain, J.-P.: A statistical comparison of SuperDARN spectral width boundaries and DMSP particle precipitation boundaries in the morning sector ionosphere, Ann. Geophys., 23, 733-743, doi:10.5194/angeo-23-733-2005, 2005.

Chisham, G., Lester, M., Milan, S. E., Freeman, M. P., Bristow, W. A., Grocott, A., MacWilliams, K. A., Ruohoniemi, J. M., Yeoman, T. K., Dyson, P., Greenwald, R. A., Kikuchi, T., Pinnock, M., Rash, J., Sato, N., Sofko, G., Villain, J.-P., and Walker, A. D. M.: A decade of the Super Dual Auroral Radar Network (SuperDARN): Scientific achievements, new techniques and future directions, Surv. Geophys., 28, 33-109, doi:10.1007/s10712-0079017-8, 2007. 
Cooling, B. M. A., Owen, C. J., and Schwartz, S. J.: Role of the magnetosheath flow in determining the motion of the open flux tubes, J. Geophys. Res., 106, 18763-18775, 2001.

Cowley, S. W. H. and Lockwood, M.: Excitation and decay of solar wind-driven flows in the magnetosphere-ionosphere system, Ann. Geophys., 10, 103-115, 1992.

Daly, P. W., Williams, D. J., Russell, C. T., and Keppler, E.: Particle signature of magnetic flux transfer events at the magnetopause, J. Geophys. Res., 86, 1628-1632, 1981.

Dungey, J. W.: Interplanetary magnetic field and the auroral zones, Phys. Rev. Lett., 6, 47-48, 1961.

Dunlop, M. W., Balogh, A., Cargill, P., Elphic, R. C., Fornaon, K.-H., Georgescu, E., Sedgemore-Schulthess, F., and the FGM team: Cluster observes the Earth's magnetopause: coordinated four-point magnetic field measurements, Ann. Geophys., 19, 1449-1460, doi:10.5194/angeo-19-1449-2001, 2001.

Dunlop, M. W., Taylor, M. G. G. T., Davies, J. A., Owen, C. J., Pitout, F., Fazakerley, A. N., Pu, Z., Laakso, H., Bogdanova, Y. V., Zong, Q.-G., Shen, C., Nykyri, K., Lavraud, B., Milan, S. E., Phan, T. D., Rème, H., Escoubet, C. P., Carr, C. M., Cargill, P., Lockwood, M., and Sonnerup, B.: Coordinated Cluster/Double Star observations of dayside reconnection signatures, Ann. Geophys., 23, 2867-2875, doi:10.5194/angeo-23-2867-2005, 2005.

Elphic, R. C., Lockwood, M., Cowley, S. W. H., and Sandholt, P. E.: Flux transfer events at the magnetopause and in the ionosphere, Geophys. Res. Lett., 17, 2241-2244, 1990.

Escoubet, C. P., Fehringer, M., and Goldstein, M.: Introduction: The Cluster mission, Ann. Geophys., 19, 1197-1200, doi:10.5194/angeo-19-1197-2001, 2001.

Farrugia, C. J., Rijnbeek, R. P., Saunders, M. A., Southwood, D. J., Rodgers, D. J., Smith, M. F., Chaloner, C. P., Hall, D. S., Christiansen, P. J., and Woolliscroft, L. J. C.: A multi-instrument study of flux transfer event structure, J. Geophys. Res., 93, 1446514477, 1988.

Fazakerley, A. N., Carter, P. J., Watson, G., Spencer, A., Sun, Y. Q., Coker, J., Coker, P., Kataria, D. O., Fontaine, D., Liu, Z. X., Gilbert, L., He, L., Lahiff, A. D., Mihalčič, B., Szita, S., Taylor, M. G. G. T., Wilson, R. J., Dedieu, M., and Schwartz, S. J.: The Double Star Plasma Electron and Current Experiment, Ann. Geophys., 23, 2733-2756, doi:10.5194/angeo-23-2733-2005, 2005.

Fear, R. C., Fazakerley, A. N., Owen, C. J., Lahiff, A. D., Lucek, E. A., Balogh, A., Kistler, L. M., Mouikis, C., and Rème, H.: Cluster observations of bounday layer structure and a flux transfer event near the cusp, Ann. Geophys., 23, 2605-2620, doi:10.5194/angeo-23-2605-2005, 2005.

Fear, R. C., Milan, S. E., Fazakerley, A. N., Owen, C. J., Asikainen, T., Taylor, M. G. G. T., Lucek, E. A., Rme, H., Dandouras, I., and Daly, P. W.: Motion of flux transfer events: a test of the Cooling model, Ann. Geophys., 25, 1669-1690, doi:10.5194/angeo-251669-2007, 2007.

Greenwald, R. A., Baker, K. B., Dudeney, J. R., Pinnock, M., Jones, T. B., Thomas, E. C., Villain, J.-P., Cerisier, J.-C., Senior, C., Hanuise, C., Hunsucker, R. D., Sofko, G., Koehler, J., Nielsen, E., Pellinen, R., Walker, A. D. M., Sato, N., and Yamagishi, H.: Darn/SuperDARN: A global view of the dynamics of highlatitude convection, Space Sci. Rev., 71, 761-796, 1995.

Haerendel, G., Paschmann, G., Sckopke, N., Rosenbauer, H., and Hedgecock, P. C.: The frontside boundary layer of the magnetopause and the problem of reconnection, J. Geophys. Res., 83,
3195-3216, 1978.

Harvey, C. C.: Spatial gradients and the volumetric tensor, in: Analysis Methods for Multi-Spacecraft Data, edited by: Paschmann, G. and Daly, P. W., pp. 307-348, ISSI, 1998.

Hasegawa, H., Sonnerup, B. U. Ö., Owen, C. J., Klecker, B., Paschmann, G., Balogh, A., and Rème, H.: The structure of flux transfer events recovered from Cluster data, Ann. Geophys., 24, 603-618, doi:10.5194/angeo-24-603-2006, 2006.

Johnstone, A. D., Burge, S., Carter, P. J., Coates, A. J., Coker, A. J., Fazakerley, A. N., Grande, M., Gowan, R. A., Gurgiolo, C., Hancock, B. K., Narheim, B., Preece, A., Sheather, P. H., Winningham, J. D., and Woodliffe, R. D.: PEACE: A plasma electron and current experiment, Space Sci. Rev., 79, 351-389, 1997.

Karhunen, T. J. T., Arnold, N. F., Robinson, T. R., and Lester, M.: Determination of the parameters of traveling ionospheric disturbances in the high-latitude ionosphere using CUTLASS coherent-scatter radars, J. Atmos. Solar Terr. Phys., 68, 558-567, 2006.

Lester, M., Chapman, P. J., Cowley, S. W. H., Crooks, S. J., Davies, J. A., Hamadyk, P., McWilliams, K. A., Milan, S. E., Parsons, M. J., Payne, D. B., Thomas, E. C., Thornhill, J. D., Wade, N. M., Yeoman, T. K., and Barnes, R. J.: Stereo CUTLASS - A new capability for the SuperDARN HF radars, Ann. Geophys., 22, 459-473, doi:10.5194/angeo-22-459-2004, 2004.

Liou, K., Newell, P. T., and Meng, C.-I.: Characteristics of the solar wind controlled auroral emissions, J. Geophys. Res., 103, 17543-17557, 1998.

Liu, Z. X., Escoubet, C. P, Pu, Z., Laakso, H., Shi, J. K., Shen, C., and Hapgood, M.: The Double Star mission, Ann. Geophys., 23, 2707-2712, doi:10.5194/angeo-23-2707-2005, 2005.

Lockwood, M.: Flux-transfer events at the dayside magnetopause - transient reconnection or magnetosheath dynamic pressure pulses?, J. Geophys. Res., 96, 5497-5509, 1991.

Lockwood, M. and Carlson, H. C.: Production of polar cap electron density patches by transient magnetopause reconnection, Geophys. Res. Lett., 19, 1731-1734, 1992.

Lockwood, M. and Hapgood, M. A.: On the Cause of a Magnetospheric Flux Transfer Event, J. Geophys. Res., 103, 2645326478, 1998.

Lockwood, M. and Smith, M. F.: The variation of reconnection rate at the dayside magnetopause and cusp ion precipitation, J. Geophys. Res., 97, 14841-14847, 1992.

Lockwood, M. and Wild, M. N.: On the quasi-periodic nature of magnetopause flux-transfer events, J. Geophys. Res., 98, 59355940, 1993.

Lockwood, M., Fazakerley, A., Opgenoorth, H., Moen, J., van Eyken, A. P., Dunlop, M., Bosqued, J.-M., Lu, G., Cully, C., Eglitis, P., McCrea, I. W., Hapgood, M. A., Wild, M. N., Stamper, R., Denig, W., Taylor, M., Wild, J. A., Provan, G., Amm, O., Kauristie, K., Pulkkinen, T., Strømme, A., Prikryl, P., Pitout, F., Balogh, A., Rème, H., Behlke, R., Hansen, T., Greenwald, R., Frey, H., Morley, S. K., Alcaydé, D., Blelly, P.-L., Donovan, E., Engebretson, M., Lester, M., Watermann, J., and Marcucci, M. F.: Coordinated Cluster and ground-based instrument observations of transient changes in the magnetopause boundary layer during an interval of predominantly northward IMF: relation to reconnection pulses and FTE signatures, Ann. Geophys., 19, 1613-1640, doi:10.5194/angeo-19-1613-2001, 2001.

Lockwood, M., Lanchester, B. S., Frey, H. U., Throp, K., Morley, 
S. K., Milan, S. E., and Lester, M.: IMF control of cusp proton emission intensity and dayside convection: implications for component and anti-parallel reconnection, Ann. Geophys., 21, 955-982, doi:10.5194/angeo-21-955-2003, 2003.

Marchaudon, A., Cerisier, J.-C., Bosqued, J.-M., Dunlop, M. W., Wild, J. A., Décréau, P. M. E., Förster, M., Fontaine, D., and Laakso, H.: Transient plasma injections in the dayside magnetosphere: one-to-one correlated observations by Cluster and $\mathrm{Su}-$ perDARN, Ann. Geophys., 22, 141-158, doi:10.5194/angeo-22141-2004, 2004.

Milan, S. E., Yeoman, T. K., Lester, M., Thomas, E. C., and Jones, T. B.: Initial backscatter occurrence statistics from the CUTLASS HF radars, Ann. Geophys., 15, 703-718, doi:10.1007/s00585-997-0703-0, 1997.

Milan, S. E., Lester, M., Cowley, S. W. H., and Brittnacher, M.: Convection and auroral response to a southward turning of the IMF: Polar UVI, CUTLASS and IMAGE signatures of transient magnetic flux transfer at the magnetopause, J. Geophys. Res., 105, 15741-15756, 2000.

Neudegg, D. A., Yeoman, T. K., Cowley, S. W. H., Provan, G., Haerendel, G., Baumjohann, W., Auster, U., Fornacon, K.-H., Georgescu, E., and Owen, C. J.: A flux transfer event observed at the magnetopause by the Equator-S spacecraft and in the ionosphere by the CUTLASS HF radar, Ann. Geophys., 17, 707-711, doi:10.1007/s00585-999-0707-z, 1999.

Neudegg, D. A., Cowley, S. W. H., McWilliams, K. A., Lester, M., Sigwarth, J., Haerendel, G., Baumjohann, W., Auster, U., Fornacon, K.-H., Georgescu, E.: The UV aurora and ionospheric flows during flux transfer events, Ann. Geophys., 19, 179-188, doi:10.5194/angeo-19-179-2001, 2001.

Owen, C. J., Fazakerley, A. N., Carter, P. J., Coates, A. J., Krauklis, I. C., Szita, S., Taylor, M. G. G. T., Travnicek, P., Watson, G., Wilson, R. J., Balogh, A., and Dunlop, M. W.: Cluster PEACE observations of electrons during magnetospheric flux transfer events, Ann. Geophys., 19, 1509-1522, doi:10.5194/angeo-191509-2001, 2001.

Paschmann, G., Haerendel, G., Papamastorakis, I., Sckopke, N., Bame, S. J., Gosling, J. T., and Russell, C. T.: Plasma and magnetic field characteristics of magnetic flux transfer events, J. Geophys. Res., 87, 2159-2168, 1982.

Pinnock, M., Rodger, A. S., Dudeney, J. R., Rich, F., and Baker, K. B.: High spatial and temporal resolution observations of the ionospheric cusp, Ann. Geophys., 13, 919-925, doi:10.1007/s00585-995-0919-9, 1995.

Pitout, F., Newell, P. T., and Buchert, S. C.: Simultaneous highand low-latitude reconnection: ESR and DMSP observations, Ann. Geophys., 20, 1311-1320, doi:10.5194/angeo-20-13112002, 2002.

Provan, G., Yeoman, T. K., and Milan, S. E.: CUTLASS Finland radar observations of the ionospheric signatures of flux transfer events and the resulting plasma flows, Ann. Geophys., 16, 14111422, doi:10.1007/s00585-998-1411-0, 1998.

Rème, H., Aoustin, C., Bosqued, J. M., Dandouras, I., Lavraud, B., Sauvaud, J. A., Barthe, A., Bouyssou, J., Camus, Th., CoeurJoly, O., Cros, A., Cuvilo, J., Ducay, F., Garbarowitz, Y., Medale, J. L., Penou, E., Perrier, H., Romefort, D., Rouzaud, J., Vallat, C., Alcaydé, D., Jacquey, C., Mazelle, C., d’Uston, C., Möbius, E., Kistler, L. M., Crocker, K., Granoff, M., Mouikis, C., Popecki, M., Vosbury, M., Klecker, B., Hovestadt, D., Kucharek, H.,
Kuenneth, E., Paschmann, G., Scholer, M., Sckopke, N., Seidenschwang, E., Carlson, C. W., Curtis, D. W., Ingraham, C., Lin, R. P., McFadden, J. P., Parks, G. K., Phan, T., Formisano, V., Amata, E., Bavassano-Cattaneo, M. B., Baldetti, P., Bruno, R., Chionchio, G., Di Lellis, A., Marcucci, M. F., Pallocchia, G., Korth, A., Daly, P. W., Graeve, B., Rosenbauer, H., Vasyliunas, V., McCarthy, M., Wilber, M., Eliasson, L., Lundin, R., Olsen, S., Shelley, E. G., Fuselier, S., Ghielmetti, A. G., Lennartsson, W., Escoubet, C. P., Balsiger, H., Friedel, R., Cao, J.-B., Kovrazhkin, R. A., Papamastorakis, I., Pellat, R., Scudder, J., and Sonnerup, B.: First multispacecraft ion measurements in and near the Earth's magnetosphere with the identical Cluster ion spectrometry (CIS) experiment, Ann. Geophys., 19, 1303-1354, doi:10.5194/angeo19-1303-2001, 2001.

Retino, A., Sundkvist, D., Vaivads, A., Mozer, F., Ander, M., and Owen, C. J.: In situ evidence of magnetic reconnection in turbulent plasma, Nature Physics, 3, 235-238, 2007.

Rijnbeek, R. P., Cowley, S. W. H., Southwood, D. J., and Russell, C. T.: A survey of dayside flux transfer events observed by ISEE 1 and 2 magnetometers, J. Geophys. Res., 89, 786-800, 1984.

Ruohoniemi, J. M. and Baker, K. B.: Large-scale imaging of highlatitude convection with Super Dual Auroral Radar Network HF radar observations, J. Geophys. Res., 103, 20797-20811, 1998.

Russell, C. T. and Elphic, R. C.: Initial ISEE magnetometer results: magnetopause observations, Space Sci. Rev., 22, 681-715, 1978.

Russell, C. T., Mellott, M., Smith, E., and King, J.: Multipoint spacecraft observations of interplanetary shocks: Four spacecraft determination of shock normals, J. Geophys. Res., 88, 47394748, 1983.

Sandholt, P. E., Lockwood, M., Oguti, T., Cowley, S. W. H., Freeman, K. S. C., Lybekk, B., Egeland, A., and Willis, D. M.: Midday auroral breakup events and related energy and momentum transfer from the magnetosheath, J. Geophys. Res., 95, 10391060, 1990.

Saunders, M. A., Russell, C. T., and Sckopke, N.: Recent ISEE observations of the magnetopause and low-latitude boundary layer: a review, J. Geophys., 52, 190-198, 1983.

Shepherd, S. G., Greenwald, R. A., and Ruohoniemi, J. M.: A possible explanation for rapid, large-scale ionospheric responses to southward turnings of the IMF, Geophys. Res. Lett., 26, 31973200, 1999.

Shi, Q. Q., Shen, C., Dunlop, M. W., Pu, Z. Y., Zong, Q.-G., Zhang, H., Xiao, C. J., Liu, Z. X., Lucek, E., and Balogh, A.: Motion of observed structures calculated from multi-point magnetic field measurements: Application to Cluster, Geophys. Res. Lett., 33, L08109, doi:10.1029/2005GL025073, 2006.

Sonnerup, B. U. Ö. and Scheible, M.: Minimum and maximum variance analysis, in: Analysis Methods for Multi-Spacecraft Data, edited by: Paschmann, G. and Daly, P. W., Int. Space Science Institute, Bern, pp. 185-220, 1998.

Southwood, D. J., Farrugia, C. J., and Saunders, M. A.: What are flux transfer events?, Planet. Space Sci., 36, 503-508, 1988.

Thomsen, M. F., Stansberry, J. A., Bame, S. J., Fuselier, S. A., and Gosling, J. T.: Ion and electron velocity distributions within flux transfer events, J. Geophys. Res., 92, 12127-12136, 1987.

Tsyganenko, N. A. and Stern, D. P.: Modeling the global magnetic field of the large-scale Birkeland current systems, J. Geophys. Res., 101, 27187-27198, 1996.

Wang, Y. L., Elphic, R. C., Lavraud, B., Taylor, M. G. G. T., Birn, J., 
Raeder, J., Russell, C. T., Kawano, H., Zong, Q. G., Zhang, H., Zhang, X. X., and Friedel, R. H.: Initial results of high-latitude magnetopause and low-latitude flank flux transfer events from 3 years of Cluster observations, J. Geophys. Res., 110, A11221, doi:10.1029/2005JA011150, 2005.

Wannberg, G., Wolf, L., Vanhainen, L.-G., Koskenniemi, K., Rottger, J., Postila, M., Markkanen, J., Jacobsen, R., Stenberg, A., Larsen, R., Eliassen, S., Heck, S., and Huuskonen, A.: The EISCAT Svalbard radar: A case study in modern incoherent scatter radar system design, Radio Sci., 32, 2283-2307, 1997.

Wild, J. A., Cowley, S. W. H., Davies, J. A., Khan, H., Lester, M., Milan, S. E., Provan, G., Yeoman, T. K., Balogh, A., Dunlop, M. W., Fornaon, K.-H., and Georgescu, E.: First simultaneous observations of flux transfer events at the high-latitude magnetopause by the Cluster spacecraft and pulsed radar signatures in the conjugate ionosphere by the CUTLASS and EISCAT radars, Ann. Geophys., 19, 1491-1508, doi:10.5194/angeo-191491-2001, 2001.

Wild, J. A., Milan, S. E., Cowley, S. W. H., Dunlop, M. W., Owen, C. J., Bosqued, J. M., Taylor, M. G. G. T., Davies, J. A., Lester, M., Sato, N., Yukimatu, A. S., Fazakerley, A. N., Balogh, A., and Rème, H.: Coordinated interhemispheric SuperDARN radar observations of the ionospheric response to flux transfer events observed by the Cluster spacecraft at the high-latitude magnetopause, Ann. Geophys., 21, 1807-1826, doi:10.5194/angeo-211807-2003, 2003.

Wild, J. A., Milan, S. E., Cowley, S. W. H., Bosqued, J. M., Rème, H., Nagai, T., Kokubun, S., Saito, Y., Mukai, T., Davies, J. A., Cooling, B. M. A., Balogh, A., and Daly, P. W.: Simultaneous insitu observations of the signatures of dayside reconnection at the high- and low-latitude magnetopause, Ann. Geophys., 23, 445460, doi:10.5194/angeo-23-445-2005, 2005.
Wild, J. A., Milan, S. E., Davies, J. A., Dunlop, M. W., Wright, D. M., Carr, C. M., Balogh, A., Rème, H., Fazakerley, A. N., and Marchaudon, A.: On the location of dayside magnetic reconnection during an interval of duskward oriented IMF, Ann. Geophys., 25, 219-238, doi:10.5194/angeo-25-219-2007, 2007.

Zhang, Q.-H., Liu, R. Y., Dunlop, M. W., Huang, J. Y., Hu, H. Q., Lester, M., Liu, Y. H., Hu, Z. J., Shi, Q. Q., and Taylor, M. G. G. T.: Simultaneous tracking of reconnected flux tubes: Cluster and conjugate SuperDARN observations on 1 April 2004, Ann. Geophys., 26, 1545-1557, doi:10.5194/angeo-26-1545-2008, 2008.

Zhang, Q.-H., Dunlop, M. W., Lockwood, M., Liu, R. -Y., Hu, H.-Q., Yang, H.-G., Hu, Z.-J., Bogdanova, Y. V., Shen, C., Zhang, B.-C., Han, D.-S., Liu, S.-L., McCrea, I. W., and Lester, M.: Simultaneous observations of reconnection pulses at Cluster and their effects on the cusp aurora observed at the Chinese Yellow River Station, J. Geophys. Res., 115, A10237, doi:10.1029/2010JA015526, 2010.

Zhang, Q.-H., Zhang, B.-C., Liu, R.-Y., Dunlop, M. W., Lockwood, M., Moen, J., Yang, H.-G., Hu, H.-Q., Hu, Z.-J., McCrea, I. W., and Lester, M.: On the importance of IMF $\left|B_{Y}\right|$ on polar cap patch formation, J. Geophys. Res., 116, A05308, doi:10.1029/2010JA016287, 2011.

Zheng, Y., Le, G., Slavin, J. A., Goldstein, M. L., Cattell, C., Balogh, A., Lucek, E. A., Rème, H., Eastwood, J. P., Wilber, M., Parks, G., Retin, A., and Fazakerley, A.: Cluster observation of continuous reconnection at dayside magnetopause in the vicinity of cusp, Ann. Geophys., 23, 2199-2215, doi:10.5194/angeo-232199-2005, 2005. 